\title{
Margarida Xirgu, presidenta de la Delegació de la Generalitat de Catalunya a la República Oriental de l'Uruguai. Cartes de Josep Tarradellas (1960-1964)
}

\author{
FRANCESC FogUet I BOREU \\ Universitat Autònoma de Barcelona
}

Resum: El 12 de maig de 1956, el president de la Generalitat de Catalunya a l'exili Josep Tarradellas creà, per decret, les figures dels delegats generals i especials que havien de representar aquesta institució en el continent europeu i en l'americà. Per a la República Oriental de l'Uruguai, nomenà la prestigiosa actriu i directora d'escena Margarida Xirgu com a «delegada general» i el doctor Miquel Cunillera, com a «delegat especial». Tot i les dificultats internes, la Delegació de l'Uruguai dugué a terme diverses accions per projectar internacionalment la veu política de la Catalunya exiliada. Aquest article examina l'activitat oficial de la delegació uruguaiana i, especialment, el paper que hi tingué Margarida Xirgu en qualitat de delegada general. Així mateix, bo i contextualitzant-les, dóna a conèixer les cartes — dipositades en el fons Margarida Xirgu de l'Arxiu Montserrat Tarradellas i Macià del Monestir de Santa Maria de Poblet— que el president de la Generalitat a l'exili envià a l'actriu durant els anys 1960-1964, en què li exposava, sobretot, la seva actuació en el terreny «diplomàtic». Amb la implicació institucional d'alt nivell que assumí, ni que fos de caràcter honorífic, s'evidencia el compromís que Xirgu mantingué envers la Generalitat i el conjunt de l'exili català.

Paraules clau: Exili català, política internacional, Generalitat de Catalunya, Margarida Xirgu, Josep Tarradellas, Delegació de la República Oriental de l’Uruguai

Abstract: On 12th May 1956, the President of the Generalitat of Catalonia in exile, Josep Tarradellas, passed a decree to create the positions of general and special delegates, who would represent the institution across Europe and the Americas. In Uruguay, the respected actress and director Margarida Xirgu was appointed as 'general delegate' and Dr. Miquel Cunillera as 'special delegate'. Despite in ternal difficulties, the delegation in Uruguay carried out a number of actions to project the voice of Catalonia in exile at an international level. This article examines the official activity of the Uruguayan delegation and, in particular, the role that Margarida Xirgu played in her capacity as general delegate. The article presents and contextualizes the letters that the President of the Generalitat in exile wrote to the actress in the period between 1960 and 1964 . These documents form part of the Margarida Xirgu collection of the Montserrat Tarradellas i Macià Archive in the Monastery of Santa Maria de Poblet. In the letters, the President mainly explains his activity in the diplomatic field. With the high-level institutional involvement that she embraced, albeit in an honorary capacity, Xirgu's commitment to the Generalitat and Catalonia in exile as a whole is abundantly clear.

Keywords: Catalan exile, international policy, Generalitat of Catalonia, Margarida Xirgu, Josep Tarradellas, Delegation of the Eastern Republic of Uruguay. 
Una de les accions que Josep Irla emprengué durant el seu mandat presidencial fou la creació de les delegacions catalanes en terres d'Amèrica. El text de la disposició oficial, signat a París l'1 de febrer de 1950, establia que la seva funció era «servir de nexe i d'intermediari entre la Presidència de la Generalitat i els catalans de la demarcació respectiva». ${ }^{1}$ Dotades del caràcter de representació institucional en el país on radiquessin, aquestes delegacions tenien com a fita general «mantenir l'esperit de Catalunya i fer-lo conèixer al país respectiu» i, en particular, fomentar «totes les activitats patriòtiques, culturals i d'assistència social», com també «estimular i coordinar l'acció de tots els elements catalans de la seva demarcació a profit de la causa antifranquista». ${ }^{2}$ Com a rerefons, hi havia la necessitat del president Irla de buscar suports econòmics entre les comunitats americanes per tal de palliar la manca de recursos de la Generalitat a l'exili, a causa de la mesquinesa i deslleialtat del Govern de la República espanyola i l'agreujament de la situació internacional amb la fi de la Segona Guerra Mundial.

Aquesta disposició presidencial encetà un debat entre les comunitats catalanes, com la de Mèxic i de l'Argentina, les més significatives, que reclamaren la creació prèvia d'un Govern o Consell Nacional a fi que exercís de portaveu nacional i dirigís l'activitat de les collectivitats de l'exiliada. ${ }^{3}$ L'eterna discòrdia dels catalans, en què Josep Tarradellas com a secretari general d'ERC tingué un paper destacat, aturà la constitució d'un nou Govern i, de retruc, estroncà la creació de les delegacions. La iniciativa d'Irla per revifar la seva acció política havia fracassat sense palliatius: «les delegacions que foren creades amb les finalitats que sabeu no rutllen», reconeixia el mateix president en una carta a Víctor Torres, des de Cogolin el 8 de juliol de $1950 .^{4}$

Sis anys més tard, el 1956, el president Josep Tarradellas recuperà la idea de les delegacions i en canalitzà la viabilitat legal per tal de formar una xarxa de representacions de la Presidència de la Generalitat de Ca-

1 Miquel Ferrer Sanchis, La Generalitat de Catalunya a l'exili (Barcelona: Aymà, 1977), 135.

2 Ferrer Sanchis, La Generalitat de Catalunya a l'exili, 137.

3 Ibid., 138-143. Vegeu també Felip Calvet i Costa \& Josep M. Roig I Rosich, Josep Irla, president de la Generalitat catalana a l'exili (Barcelona: Fundació Salvador Vives Casajuana, 1983), 273274 .

4 Josep Irla i Bosch, Memòries d'un president a l'exili, edició a cura de Jordi Gaitx Moltó (Barcelona: Viena, 2010), 168-169. 
talunya tant a l'interior com a l'exili. En efecte, el decret del 12 de maig de 1956, publicat al Diari Oficial de la Generalitat de Catalunya, del juny del mateix any, donava via lliure al nomenament de delegats generals i especials «a Catalunya i en els territoris on l'emigració catalana ho justifiqui», segons especificava l'article primer. ${ }^{5}$ En el preàmbul s'argumentava la situació de manca de «jurisdicció territorial» amb què havia quedat la Generalitat amb l'ocupació del territori per l'exèrcit franquista, es feia una síntesi de les vicissituds viscudes per la institució des d'aleshores i, d'acord amb el precedent legal, es justificava la potestat que tenia el president de confiar la seva representació i d'establir delegacions de la Generalitat arreu on calgués.

Segurament, Tarradellas freturava d'establir unes delegacions de la Generalitat a l'interior i a l'exili per reforçar la institució que presidia i per trobar un suport no tan sols de caràcter econòmic, sinó també de legitimació política. Mitjançant una «ordenança de necessitat», el decret del 12 de maig de 1956 instituïa el nomenament dels delegats generals i especials, i les funcions que havien d'assumir, sense que enlloc es concretés cap dotació econòmica per al seu funcionament. Al capdavall, dissenyades des d'una òptica molt presidencialista, les delegacions es convertiren en una xarxa - entre oficial i confidencial- d'intercanvis, converses i epístoles de Tarradellas amb les personalitats de l'exili o de l'interior de la seva confiança, adhesió o lleialtat, que n'assumien la funció de delegats personals.

Com en el cas d'Irla, l'establiment de les delegacions generà una nova polèmica contra el president Tarradellas que fou acusat per alguns cenacles polítics d'exiliats d'instigar un poder de caràcter «personalista» i de no voler formar govern, fet que reobrí el debat sobre aquesta qüestió — «la gran pedra de la discòrdia» de la seva presidència, segons Ernest Udina. ${ }^{6}$ A posteriori, el mateix Tarradellas reconeixia la importància que va tenir la xarxa de delegacions com a representació institucional a l'exili, però també com a «contrapès polític»:

5 Decret del 12 de maig de 1956, signat pel president Josep Tarradellas a Mèxic (Diari Oficial de la Generalitat de Catalunya, editat a l'exili, juny 1956, 3). Reproduït també a Fer rer SAnChIs, La Generalitat de Catalunya a l'exili, 178-179.

6 Ernest Udina, Josep Tarradellas, l'aventura d'una fidelitat (Barcelona: Edicions 62, 1978), 288. 
Menys a Mèxic i Paraguai, vaig nomenar delegats meus a quasi tots els països de Sud-Amèrica, a Argentina, Xile, Perú, Uruguai, Brasil, Veneçuela. Els diaris d'aquells països en parlaven sovint, d'aquestes delegacions, els delegats de les quals m'escrivien contínuament i informaven de les accions i discursos del president a les colònies d'exiliats. Es tractava sobretot de mantenir viva la flama de la Generalitat. En principi, vaig pensar que potser també es podria fer una delegació a Catalunya. Però la cosa no passà d'una formulació en principi. De fet, ningú no volia ésser-ho perquè ningú no podia ésser-ho, si no és que volgués anar directament a la presó. Va ésser important a l'exili durant molts anys l'acció de les delegacions i també fou una manera d'evitar la creació d'un govern a l'exili, sobre el qual vaig vèncer totes les pressions. ${ }^{7}$

Ara bé, el decret de Tarradellas que creava les delegacions no fou «lletra morta», com deixà escrit Miquel Ferrer amb tota la mala intenció. ${ }^{8}$ No es desplegà, de segur, en els termes grandiloqüents que indicava la disposició oficial, perquè ni a Catalunya ni a Europa no hi hagué una xarxa tan definida i articulada en termes oficials com a Amèrica, però el fet és que, a més dels nomenaments, algunes delegacions van dur a terme una mínima activitat, de caire simbòlic, que no es pot oblidar ni menystenir. El cas de la delegació de la República Oriental de l'Uruguai, presidida per l'actriu i directora d'escena Margarida Xirgu n'és un exemple. Però no deu ser l'únic. Encara cal estudiar fins a quin punt i com es materialitzà aquesta «política de delegacions» a l'interior i a l'exili. Sabem, en tot cas, que al continent americà es crearen les més actives i de més influència en la política d'extensió tarradellista en països com ara l’Argentina, Bolívia, el Brasil, Colòmbia, Mèxic, Perú, l’Uruguai, Veneçuela o Xile. ${ }^{9}$

7 Ibid., 286.

8 Ferrer Sanchis, La Generalitat de Catalunya a l'exili, 18o.

9 Segons el Butlletí d'Informació de la Generalitat de Catalunya editat pel Servei d'Informació i Publicacions de la Generalitat de Catalunya el juliol de 196o, les delegacions constituïdes eren les següents (entre parèntesis els seus integrants): Argentina (Joan Cuatrecasas, president; Josep Santaló, delegat especial; Francesc Arnó, Joan Bas Colomer, Josep Carbó, Andreu Dameson, Timoteu Mas, Joan Merli, Ricard Rossell i Jaume Vachier, membres), Bolívia (Pere Puig i Subirats, delegat general), Brasil (Francesc de Paula Marquès, president; Josep Montfort, delegat especial; Salvador Puigvert i Salva dor Riera, membres), Colòmbia (Pere Barenys i Arnau, delegat general), Mèxic (Antoni Maria Sbert delegat general; Màrius Calvet i Arce, secretari de la Generalitat), Perú (Josep Muxi, delegat general), Uruguai (Margarida Xirgu, presidenta; Miquel S. Cunillera i Rius, delegat especial; Josep Barberà Benet, Joan Garcia Grau, Llorenç Masferrer i Antoni Trilla, membres), Veneçuela (Marc Aureli Vila, de- 
Amb tots els delegats generals o especials Tarradellas hi mantingué una intensa correspondència per mitjà de la qual els informava bàsicament de les accions de projecció exterior que endegava la Presidència de la Generalitat a l'exili. N'estava molt agraït, de l'adhesió que havia trobat en les collectivitats catalanes del centre i sud-amèrica, perquè li havia permès de nomenar delegacions de la Generalitat pertot, «representades per vells residents i exiliats» que demostraven, al seu parer, «la gran unitat dels catalans per damunt de les discrepàncies que existeixen en tota democràcia». ${ }^{10}$ Fins i tot, dedicà un dels seus «missatges oficials» als delegats i a les delegacions de la Generalitat a l'interior de Catalunya i a l'exili, datat a França el 14 d'abril de 1960, en què fixava precisament la seva proposta d'una «política nacional» diferenciada de l'espanyola. ${ }^{11}$

\title{
Xirgu, una candidata de prestigi i de consens
}

\author{
A la República Oriental de l'Uruguai, el president Tarradellas hi nomenà \\ Margarida Xirgu com a «delegada general» del Govern català, amb resi- \\ dència oficial a la ciutat de Montevideo (Colonia 881, pis 10, dep. 27). Molt \\ més tardana que en altres casos, la designació es féu efectiva a Mèxic el 12
}

\footnotetext{
legat general; Emili Pla, delegat especial) i Xile (Pere Mir i Tauler, president; Pelai Sala, delegat especial; Cristià Aguadé, Antoni Blàvia, Celestí Morlans Pujol, membres). S'anunciava també que s'havien instituït delegacions a Costa Rica, Cuba, Equador, Panamà, República Dominicana i República del Salvador, per bé que no es publicaven els noms dels catalans que les integraven «a causa dels règims polítics d'aquests països». Vegeu «Delegacions de la Generalitat de Catalunya», Butlletí d'Informació de la Generalitat de Catalunya [París] 26 (jul. 1960): 5-6. En opinió d'Ernest Udina, Joan Cuatrecasas i Antoni M. Sbert van ser els dos «homes de Tarradellas» que, a l'exili, van dur a terme «una acció més eficaç», Udina, Josep Tarradellas, l'aventura d'una fidelitat, 285.

10 Josep TARradellas, «Declaracions del president», Catalunya [Buenos Aires] 68 (ag. 1959): 6-8.

11 Josep TARRADellas, «Missatge als delegats i a les delegacions de la Generalitat a l'interior de Catalunya i a l'exili», Butlletí d'Informació de la Generalitat de Catalunya [París] 25 (abr. 1960): 2-3. En aquesta declaració, Tarradellas no hi estalvià les apellacions solemnes a la fidelitat envers els «deures i responsabilitats» i a la «lleialtat a la pàtria», que impedissin cap desviació en la «ruta» de la defensa de la «personalitat nacional»; ni hi deixà de referir-se a la «unitat catalana» que havia de dur al triomf dels ideals, si se superaven els «perills», ni tampoc de remarcar el seu «optimisme» per les coincidències que observava amb els catalans que anhelaven «portar a Catalunya la llibertat». Sense oblidar-se de recórrer al passat històric i als referents de Prat i Macià, Tarradellas també hi defensava el paper de la Generalitat com a eix de la unitat catalana i de la política nacional que calia dur a terme, en virtut de la qual Catalunya havia de «plantejar els seus drets i els seus problemes» $\mathrm{i}$ havia de «treballar per resoldre'ls d'acord amb les seves conveniències i necessitats», tot fent compatible el patriotisme i «el desig de fer d'Espanya un gran poble», però també tot tenint en compte el tracte rebut.
} 
d'agost de 1959, d'acord amb allò que preveia l'article primer del decret de la Presidència del 12 de maig de 1956 que hem comentat. Hi devia contribuir el gran prestigi que Xirgu gaudia no únicament entre l'exili català, sinó en terres americanes en general. Sense anar més lluny, en una entrevista per al setmanari Destino del 15 de març de 1958 - que Tarradellas guardà zelosament en l'arxiu personal— Josep Pla hi encimbellà Xirgu al zenit de «la mayor actriz de la América Latina». ${ }^{12}$

La Humanitat, portaveu d'Esquerra Republicana de Catalunya, el partit al qual pertanyia Tarradellas, publicà una nota breu sobre la presa de possessió del càrrec en què aclaria que Xirgu, «contràriament als rumors que havia fet circular la premsa franquista, segueix a l'exili», i també informava que, amb motiu del nomenament, havia estat «molt felicitada per tots els estaments polítics i socials del país, on l'exímia actriu compta amb un gran prestigi que honora, a l'ensems, a tots els catalans». ${ }^{13}$

En primera instància, el president Tarradellas sondejà Josep Roig i Vidal, un dels seus homes de confiança a l'Amèrica llatina, ${ }^{14}$ perquè assumís la presidència de la Delegació de l'Uruguai, però aquest va declinar l'oferiment i, com a alternativa, va proposar que s'hi designés Margarida Xirgu. A parer de Roig i Vidal, tal com manifestà en una carta a Tarradellas datada a Montevideo el 6 d'agost de 1959, l'opció de Xirgu era «una solució ideal»:

La Xirgu, estimada per tots els catalans amb contactes i relacions en totes les esferes polítiques, socials, artístiques i diplomàtiques, al front de la Delegació, donaria categoria i relleu a la mateixa.

Moltes portes se li obririen a la Margarida Xirgu, la qual cosa seria molt difícil que ho logrés una altra persona. Un document emanat de la Generalitat que tingui caràcter públic, encara que vagi adreçat als catalans, i que hagi de ser signat pel president de la Delegació de l'Uruguai, tindrà una millor acolli-

12 José PlA, «Calendario sin fechas. Margarita Xirgu», Destino 1.075 (15 març 1958): 19. Vegeu l'annex 1. Segurament, la lectura d'aquest article encomiàstic va subvenir a fer que Tarradellas no tingués cap mena d'inconvenient a l'hora d'acceptar la designació de Xirgu com a presidenta de la Delegació de l'Uruguai.

13 «Margarida Xirgu presideix la Delegació de la Generalitat a l'Uruguai», La Humanitat. Portaveu d'Esquerra Republicana de Catalunya [Mèxic DF], tercera època, 10-12 (abr--juny de 1960): 12.

14 Nascut a Vilafranca del Penedès el 1901, Josep Roig i Vidal era empresari. Des del 1951 residia a l'Uruguai, on havia creat una empresa de productes dentals, però als anys seixanta tornà definitivament a Barranquilla (Colòmbia), on s'havia installat en el primer exili. 
da si va signat per la Margarida Xirgu, que no que ho sigui per un Roig que gairebé no coneix ningú.

Considerant el renom de què gaudia Xirgu entre l'exili català, Tarradellas no tingué cap objecció, ans al contrari, a escollir-la com a presidenta de la delegació uruguaiana i encomanà al mateix Josep Roig i a Miquel S. Cunillera - un altre dels seus homes de confiança- ${ }^{15}$ que fessin les gestions pertinents per convèncer-la. En una lletra datada a Saint-Martin-leBeau el 9 de setembre de 1959, Tarradellas corroborava l'opinió de Roig: «si la senyora Xirgu acceptés fóra una gran solució [...]. Si la senyora Xirgu acceptés, això fóra un gran èxit no solament per als catalans que viviu a l'Uruguai, sinó per a tothom, car el nom i el prestigi d'aquesta és una cosa viva entre nosaltres».

Abans fins i tot de la constitució oficial de la Delegació de la Generalitat de Catalunya a la República Oriental de l'Uruguai, el president Tarradellas en formalitzà ja, de Mèxic estant, els nomenaments dels membres, el 12 d'agost de 1959, d'acord amb el que preveia el decret de Presidència que hem citat del 12 de maig de $1956 .{ }^{16}$ Encapçalada per Margarida Xirgu, com a delegada general, i Miquel S. Cunillera, com a delegat especial, la

15 Nascut al Palau d'Anglesola el 1904, Miquel dels Sants Cunillera i Rius era metge. Havia estat diputat del Parlament de Catalunya durant la República. S'exilià a França, després a Xile i a l'Uruguai. Als darrers anys, s'installà a Andorra, on exercí la medicina a les Escaldes. A l'AMTM hi ha una nombrosa correspondència entre Cunillera i Tarradellas, que abraça els anys 1946-1976. Entre les cartes circumscrites al període 1960-1964 que s'intercanviaren, totes datades a Montevideo, destaquem-ne almenys tres. En la del 5 de maig de 1962, Cunillera valorava la «trilogia» Ángel Curotto, Justino Zavala Muniz i Margarida Xirgu com a «elements que dominen tot lo relacionat amb el teatre de l'Uruguai, a part d'elements importantíssims dintre la collectivitat "colorada" políticament». En la del 7 de desembre de 1963, li explicava les dificultats que tingué per situar «al lloc d'honor pertinent» la Generalitat de Catalunya en els Jocs Florals que van tenir lloc a Montevideo el 20 d'octubre d'aquell any i, alhora, li exposava la implicació de l'actriu en el certamen, una prova més del vincle que tingué amb l'exili català: «És clar que l'acte "el robaren” la presència de la nostra Margarida i de Zavala Muniz i, sobretot, el magnífic enquadrament del Teatre Solís [...]. A propòsit de la Xirgu, sabràs que han deixat l'apartament que tenien usufructuant a Montevideo i que han anat a viure definitivament al seu xalet de Punta Ballena [...]. Tant ella com el seu espòs, l'amic Ortín, estan excellentment de salut i molt bé, i és clar que aquest estiu, amb l'arribada de [Joan] Rocamora i [Joan] Cuatrecasas, estaran d'allò més bé allà. Per altra part, cada fi de setmana no li manquen amics que els vagin a visitar». D’altra banda, Tarradellas adreçà a Cunillera una missiva, la datada el 2 de maig de 1963, en què el president a l'exili manifestà la seva estima a «tot el que l'Uruguai ha fet per tots vosaltres i per la seva simpatia i afecte envers la nostra gran Margarida Xirgu».

16 Sobre els nomenaments oficials, vegeu l'annex 2-5. 
resta d'integrants de la Delegació serien, en principi, Josep Barberà i Benet, Francesc Bergós i Ribalta, Joan Garcia i Grau, i Llorenç Masferrer. ${ }^{17}$ En qualitat de delegada general, Xirgu havia d'assumir les funcions corresponents, segons allò que establien els punts $a$ ), $b$ ) i c) de l'article segon del decret suara esmentat del 12 de maig de 1956, ço és:

a) Promoure i coordinar les tasques que portin a terme les organitzacions catalanes, o constituïdes per catalans i nacionals dels països de llur respectiva residència, per a la defensa de les llibertats democràtiques de Catalunya i de la cultura catalana.

b) Representar la Presidència de la Generalitat en les relacions amb les entitats abans esmentades i les públiques o particulars dels països en els quals s'exerceixi la Delegació, i en relació amb les institucions de la República espanyola i els seus representants a l'exterior.

c) La coordinació, d'acord amb la Presidència de la Generalitat, de la comesa dels delegats especials que resideixin en el territori atribuït a la delegació general.

Inicialment, Xirgu s'hi va resistir «per por d'haver de fer discursos», però degué decidir-se favorablement quan li plantejaren que el càrrec era «gairebé honorífic». ${ }^{18}$ Pel que sembla, l'actriu catalana va acceptar el

17 Individualment, Josep Barberà, Francesc Bergós i Ribalta, Joan Garcia i Grau i Llorenç Masferrer van rebre una notificació datada a Mèxic, el 12 d'agost de 1959, que deia així: «Per resolució d'aquesta Presidència, signada en el dia d'avui, i a proposta del delegat general de la República de l'Uruguai, senyora Margarida Xirgu, heu estat designat per a formar part de la Delegació a aqueixa República. | La qual cosa us comunico per al vostre coneixement i als efectes que escaiguin». De tots quatre, el metge Francesc Bergós i Ribalta, nascut a Barcelona el 1903, era el que gaudia de més notorietat pública. Després d'haver estat a l'Argentina, Bolívia i Xile, s'establí a l'Uruguai, on fou professor de tàctica sanitària a l'Escola de Sanitat Militar i a la Facultat de Medicina de Montevideo. Presidí el Casal Català de Montevideo (1957 i 1966) i, quan es dividí el 1961, fundà la Llar Catalana. Quatre anys més tard, el 1965, tornà al Casal Català. El 1972, fou nomenat delegat general per a l'Uruguai per mitjà d'una ordre datada el 17 de novembre d'aquell any a Saint-Martin-le-Beau, «per tal que els catalans de l'Uruguai siguin informats per aquesta Presidència de les seves activitats, i també perquè els sigui possible de fer arribar a aquesta els seus anhels i les seves inquietuds».

18 «La Margarita m'havia explicat — reportava Cuatrecasas en una lletra a Tarradellas datada a Buenos Aires el 30 d'agost de 1959- el vostre oferiment i lo que li agrada; vaig tenir la impressió que no acceptà per por d'haver de fer discursos. Ella diu que no és per ella el prendre iniciatives i parlaments. Potser, si se li digués que no ha de fer res més que presidir amb caràcter gairebé honorífic, acceptaria». 
nomenament «encantada», amb bona predisposició per collaborar amb Tarradellas, un cop, això sí, Roig i Cunillera la visitaren, li n'explicaren els motius i li mostraren la documentació allusiva, segons reportava aquest darrer en una carta a Josep Tarradellas, datada el 24 de setembre de 1959. L'entrevista tingué lloc el dia abans, el 23 de setembre, a les sis de la tarda, a Montevideo, amb la presència del marit de l'actriu Miguel Ortín. Roig Vidal referia així a Tarradellas la reunió en una carta datada a la capital uruguaiana aquell mateix dia: «Hi va haver algunes resistències de part de la senyora Xirgu, reforçades amb observacions del seu marit, però no varen ésser insalvables i, després d'un rato d'argumentar uns i altres, la senyora Margarida Xirgu va acceptar la presidència de la Delegació de la Generalitat de Catalunya a l'Uruguai».

No obstant això, la constitució de la Delegació no estigué mancada de bon començament de conflictes i malavinences, tal com deixava entreveure Tarradellas en una carta a Cunillera, datada a Saint-Martin-le-Beau el 21 de desembre de 1959: "Ja sé les divergències que s'han produit, però a mi em sembla que tots sou prou amics i teniu prou sentit de la responsabilitat per arribar a una coincidència efectiva. És l'únic país de tota l'Amèrica en què els meus propòsits estan encallats, i confio amb la teva sempre cordial i fidel amistat, per tal d'ajudar a resoldre aquesta situació». Pocs mesos abans de la constitució oficial, Cunillera manifestà, en una lletra datada a Montevideo, el 9 de gener de 1960, que els antagonismes entre Bergós, d'una banda, i Barberà i Masferrer, de l'altra, continuaven (de fet, sembla que venien de lluny), però que, al cap i a la fi, el més interessant de la Delegació seria la delegada general, o sigui, Margarida Xirgu: «Havent obtingut d'ella l'acceptació, lo més important, els demés no crec que siguin tan importants com per creure's amb dret de venir-te a demanar ni explicacions».

Per desencallar la situació, el president Tarradellas s’apressà a donar carta blanca a Cunillera, com a delegat especial, perquè creés al més aviat possible la Delegació de l'Uruguai, que, després d'un tens estira-i-arronsa, fou oficialment constituïda a la ciutat de Montevideo el 25 de març de 1960. ${ }^{19}$ L'acta fundacional deixa constància que el doctor Francesc Bergós no acceptà la designació «per raons personals» i que finalment els mem-

19 Vegeu l'annex 6. 
bres de la nounada Delegació eren, a més de Margarida Xirgu, que la presidia, el doctor Miquel Cunillera, com a delegat especial, i Josep Barberà, Joan Garcia Grau i Llorenç Masferrer.

\section{Crisi de la Delegació}

De tota manera, les dificultats constituents no van trigar gaire a aflorar, malgrat que es disposés de Xirgu com a aglutinadora de consensos, per raó del gran prestigi de què gaudia a l'Amèrica llatina. Tres dels membres de la Delegació, Barberà, Garcia i Masferrer, van enviar una missiva a Tarradellas, amb data del 7 de setembre de 1960, en què li exposaven clarament que «la cosa no marxa. La Delegació resulta inoperant», «la Delegació de fet no existeix», ja que només s'havia reunit «una vegada»; per si això no fos prou revelador, atacaven l'arbitrarietat de Cunillera com a delegat especial, ${ }^{20}$ perquè anava massa al seu aire, $i$ amenaçaven ras i curt amb la dimissió. Al seu torn, Cunillera feia saber a Tarradellas, en una lletra datada a Montevideo el 5 de novembre de 1960, que el «grup» discrepant estava «entestat en organitzacions burocràtiques internes fins i tot d'una mica de mal gust», com si es tractés d'«un comitè més», però creia que ja els passaria; en tot cas, tant la Xirgu com el doctor Anton Trilla -que segons sembla també formava part de la Delegació, tot i que no en consti el nomenament en els papers oficials ${ }^{21}$ estaven «perfectament identificats en tota l'amplitud» amb Tarradellas, «i a les seves incondicionals ordres, esperant solament les teves informacions i instruccions, sense discutir ni voler sentar càtedra de més saberuts».

En la carta de resposta a Barberà, Garcia i Masferrer, datada a SaintMartin-le-Beau el 26 de gener de 1961, Tarradellas mirà d'apaivagar els ànims dels tres membres díscols de la Delegació uruguaiana i els pregà que es mantinguessin en el seu lloc, després d'admetre que «el problema

20 Ben mirat, les atribucions del delegat especial eren molt àmplies i depenien molt de la discrecionalitat del president, si fem cas del que diu l'article tercer del decret del 12 de maig de 1956: «Les delegacions especials tindran a llur càrrec la gestió i l'orientació, d'acord amb la Presidència de la Generalitat, dels afers que aquesta cregui convenient encarregar-los temporalment o per temps in definit, tot fixant en els nomenaments respectius la comesa i el territori de cada delegació especial».

21 Nascut a les Avellanes el 1908, Anton Trilla i Sanuy era metge, pintor i músic. Establert a l'Uruguai, exercí la medicina i presidí el Casal Català de Montevideo durant els períodes 1945-1946 i 19751978. 
de les Delegacions a tot arreu ha estat sempre ben complicat, però em cal reconèixer que en el que es refereix a l'Uruguai ha estat des del començament un xic difícil». El mateix dia, va escriure també a Cunillera una lletra en què li adjuntava una còpia de l'esmentada carta del «grup» i, tot expressant-li la seva «total confiança» i relativitzant l'incident, li demanava que convoqués una reunió per llegir plegats un dels Informes confidencials que els remetria ben aviat i que - com es pot comprovar amb les lletres que editem - eren l'autèntica dèria de Tarradellas en aquells anys.

L'estiu de 1961, en una missiva datada a Montevideo el 25 d'agost, Cunillera parlava ja en termes de «crisi» oberta de la Delegació, motivada pels enfrontaments interns, diferències i discussions de procediment - molt habituals en les entitats d'exiliats - en el si del Casal Català de Montevideo que tenien, justament, com a principals impulsors el grup Barberà, Garcia i Masferrer. De resultes de les discòrdies casalenques es constituí una nova entitat, liderada pel doctor Bergós, que duia per nom «Llar Catalana».22 Cunillera posava aquesta nova entitat al servei de les activitats patriòtiques i de la collaboració amb la política tarradellista. Com a conseqüència d'aquesta escissió, la Delegació també se'n ressentí amb una «crisi» en tota regla que, fet i fet, era constituent:

Crisi, que és la mateixa que plantejà Bergós, per no formar-ne part, i que jo acceptava, pels vells lligams que tinc amb tu, i buscant la millor solució i ajut a la teva actuació. No cal que et digui, al mateix temps, que tant la senyora Xirgu com el mateix doctor [Joan] Cuatrecasas [...] estan plenament identificats amb l'actitud presa per nosaltres, que [...] servirà per aclarir l'ambient i posar les coses al seu lloc.

Barberà i Masferrer van abandonar la Delegació, que sens dubte dominava Cunillera amb el plàcet presidencial. Quan s'assabentà dels fets, Tarradellas no se'n sorprengué gaire. En la resposta a Cunillera, datada el 2 de setembre de 1961, trobà que era evident que les dissensions internes aca-

22 Llar Catalana era una entitat constituïda a Montevideo el 1961, a causa de les desavinences internes del Casal Català. Fou presidida pel doctor Francesc Bergós i Ribalta, amb el doctor Anton Trilla de vicepresident i Miquel Pascual de secretari. El 1965, els seus membres reingressaren a l'entitat mare. Entre les seves activitats, cal destacar l'organització dels Jocs Florals de la Llengua Catalana, celebrats al Teatre Solís de Montevideo, el 20 d'octubre de 1963, amb l'actriu Margarida Xirgu de presidenta. 
bessin com el rosari de l'aurora, reiterà novament la confiança en el seu delegat especial i, tot considerant que es tractava d'un afer d'abast local, opinà que era millor no remoure més el tema i deixar les coses «com estan».

Comptat i debatut, si bé era molt important, per la seva acció política, d'afermar els llaços amb els nuclis d'exiliats catalans a Amèrica o a Europa, el president Tarradellas tenia, no cal dir-ho, preocupacions molt més greus per atendre. Calia vetllar per les bones relacions amb els governs dels estats, especialment amb el francès, i mantenir la tensió dialèctica amb els representants de la República espanyola a l'exili, amb els quals les avinences no eren gens fàcils. Calia també reforçar com fos la seva legitimació presidencial, permanentment qüestionada pel seu propi partit i per les altres forces polítiques, tant a Catalunya com en la diàspora. I, encara, havia de solucionar els conflictes tàctics que ell mateix de tant en tant contribuïa a crear, moltes vegades a causa del zel estratègic a convertir la Generalitat que presidia en l'únic i exclusiu interlocutor vàlid en totes les negociacions i pactes que es fessin a l'interior o a l'exili.

\section{Accions de la Delegació de l’Uruguai}

Entre les «accions» en què participà Xirgu com a delegada general a l'Uruguai de la Generalitat de Catalunya a l'exili, destaquem la signatura de dues cartes d'alt contingut simbòlic: la primera, del 12 d'octubre de 1961, al senador Luis Batlle Berres, director també del diari Acción de Montevideo, i, molt especialment, la segona, del 7 de desembre del mateix any, al president dels Estats Units d'Amèrica John Fitzgerald Kennedy. ${ }^{23}$ Tot $\mathrm{i}$ l'abast diferent de cadascuna, en tots dos casos es tractava de projectar, en l'àmbit internacional, la veu política de Catalunya per mitjà de la seva figura institucional més rellevant, Josep Tarradellas, com a representant de facto de la catalanitat exiliada.

Escrita segurament per Cunillera, la carta al senador Batlle és una expressió del condol per la mort del conseller nacional Manuel Rodríguez

23 Vegeu respectivament l'annex 7 i 8. En nom de la collectivitat catalana, la delegació de la Generalitat de Catalunya a l'Uruguai i el president Tarradellas, Cunillera en solitari va escriure també una carta a Emilio A. Masobrio, director de Passeigs Municipals de Montevideo, datada en aquesta ciutat el 20 de gener de 1962, per agrair-li l'embelliment de la plaça que, a la capital uruguaiana, duia el nom i retia memòria al president Lluís Companys. Vegeu l'annex 9. 
Correa, un polític uruguaià que pertanyia al Partido Colorado i que havia estat membre del Consell Nacional del Govern entre 1959 i 1961. Subratllem que la condolença es feia en nom de la «sojuzgada y doliente democracia catalana, y de su legítimo representante el presidente de la Generalitat Honorable Señor José Tarradellas». Cal tenir en compte, d'altra banda, la significació política de Batlle, que havia estat president de l'Uruguai entre 1947 i 1951 i, posteriorment, entre 1955 i 1956, i també la seva ascendència catalana, que podia fer-lo més sensible al plet de Catalunya, per tal com era nebot del cèlebre polític i estadista José Batlle y Ordóñez, que l'havia precedit en la presidència de la República de l'Uruguai en dues avinenteses (1903-1907 i 1911-1915).

Molta més significació política té la segona missiva que Xirgu signà juntament amb Joan Cuatrecasas (delegat de la República Argentina), Josep Santaló (delegat especial del president de la Generalitat) i Miquel Cunillera (delegat especial a l'Uruguai). Datat a Buenos Aires, aquest document fou escrit per Cuatrecasas i disposà del vistiplau explícit de Xirgu, tal com comenta ell mateix en una lletra a Tarradellas, del 24 de desembre de 1961, des de la capital argentina:

Com que jo vaig estar quatre dies a l'Uruguai, la Margarita el trobà molt bé i hi posà la firma. Són petits grans de sorra, que és lo poc que nosaltres podem fer. Hem procurat sempre que cap frase o paraula no pugui ésser mal interpretada. [...] La signatura de la Margarita Xirgu és coneguda i important. En Kennedy fa cas d'aquestes advertències.

Arran del concert que Pau Casals va oferir a la Casa Blanca el 13 de novembre de 1961, convidat personalment per Kennedy, els signants de la missiva al president dels EUA manifestaven la seva esperança que la repercussió artística i política d'aquest acte, tan simbòlic, seria un punt d'inflexió en la política exterior nord-americana. Des dels Pactes de Madrid de 1953, com és conegut, els EUA havien reforçat, per al bé de l'imperi, la dictadura franquista en l'àmbit internacional. ${ }^{24}$ Tanmateix, amb

24 Sobre les relacions entre el franquisme i els EUA, vegeu, per exemple, Ángel ViñAs, Los pactos secretos de Franco con Estados Unidos: bases, ayuda económica, recortes de soberanía (Barcelona: Grijalbo, 1981), i Manuel EsPadAs Burgos, Franquismo y política exterior (Madrid: Rialp, 1988). 
l'arribada de Kennedy a la presidència dels EUA el 1961, que prenia el relleu a Eisenhower, el manteniment d'aquesta política entrava en contradicció, com apuntaven els signants de la carta, amb la defensa de la llibertat que es trobava a la base de les Nacions Unides i els valors democràtics que el partit de Kennedy es vanagloriava de defensar.

Els signataris de la lletra al president dels EUA, que ho feien en qualitat de delegats de la Generalitat a l'exili, criticaven que la política nordamericana obviés que donava suport a una dictadura feixista, advertien del perill que, en plena Guerra Freda, el comunisme es guanyés les simpaties de l'oposició antifranquista amb una progressiva radicalització i, en definitiva, reclamaven una rectificació de la política internacional que permetés que el poble espanyol i el català recuperessin la democràcia. En aquest sentit, asseguraven que el president de la Generalitat a l'exili - una institució que creien de consens entre els catalans - es trobava a punt per assumir la «reconstrucció democràtica» i la transformació política que reclamava l'Estat espanyol. No n'hi havia prou amb discursos o proclames, gosaven advertir a Kennedy, calia una acció diplomàtica efectiva que apostés per un viratge democràtic.

Pocs dies després, en una lletra adreçada a Cuatrecasas, del 10 de febrer de 1962, Tarradellas felicitava els sotasignats de la carta al president Kennedy i expressava la seva conformitat amb el text:

Molt em va plaure el seu contingut, tant pel pensament que en tota ella hi batega com pel to i la manera d'exposar els nostres anhels. Més que una carta és un document, despullat de retòrica, sense tòpics i ple d'una noble ambició pel futur del nostre poble i de la democràcia. Francament, em sembla que, si tots els exiliats catalans i espanyols fessin un esforç, en cada ocasió que es presenta, per a plantejar els nostres problemes amb la intelligència que ho heu fet en aquesta carta, cada dia guanyaríem més posicions en la batalla que fa tants anys mantenim.

La bona sintonia entre Tarradellas i Xirgu, que es féu evident en alguna trobada esporàdica en què van coincidir als anys cinquanta, és corroborada també pels comentaris que fa el seu amic Cuatrecasas en les cartes que enviava al president a l'exili. En una de les missives, datada a Punta Ballena el 7 de febrer de 1962, per exemple, l'amic doctor de Xirgu —amb 
la qual compartia veïnatge a Punta Ballena- confessava al seu illustre destinatari el següent:

Ja fa uns dies que estem a Punta Ballena, disfrutant de la platja i de la meditació. Podeu suposar com us recordem i com revivim aquelles hores que la raconada d'Ull de Ter va fruir de la vostra presència. La Margarida Xirgu fa seva també aquesta lletra, atès que cada dia fem els comentaris de les notícies mundials i esbravem les esperances del proper retorn, bo i recordant els nostres poetes:

\author{
«Ja hi tornaran de parella en parella! \\ Tota ma pàtria cabrà en eixa anella, \\ i els pobles diran: \\ la sardana és la dansa més bella.... ${ }^{25}$
}

Sembla que l'hora es va acostant; totes les circumstàncies coincideixen cap a la ràpida eliminació del corc pudent que paralitza el destí de la nostra pàtria.

\title{
«Distingida presidenta»
}

Com amb la resta de delegacions, Tarradellas entaulà una certa correspondència amb Xirgu, en qualitat de presidenta de la Delegació de la Generalitat de Catalunya a la República Oriental de l'Uruguai, si més no entre el 8 d'abril de 1960 i el 2 de gener de 1963, tal com proven les nou cartes (1-9) que editem a continuació i que es troben dipositades a l'Arxiu Montserrat Tarradellas i Macià (AMTM) del Monestir de Santa Maria de Poblet. Amb la solemnitat que el caracteritzava, el president Tarradellas en persona s'adreçà a l'actriu per mantenir-la al corrent de la seva acció política. Sorprenentment, l'única missiva que ens consta que envià Xirgu a Tarradellas (c. 10) és una postal nadalenca, escrita a Punta Ballena, en una data tan tardana com el desembre de 1964, quan la Delegació uruguaiana era ja gairebé una entelèquia.

25 «de totes les danses que es fan i es desfan». Fragment de la darrera part del poema «La sardana», de Joan Maragall, inclòs dins Visions \& Cants (1900). 
Al marge de l'agraïment de cortesia per haver acceptat de presidir la delegació (c. 1), Tarradellas s'afanyava en l'epistolari amb Xirgu a recordar-li la remesa dels informes confidencials (que de fet enviava a molts destinataris, de manera que el factor de confidencialitat era més aviat relatiu) i, amb un optimisme estratègic, a fer-la partícip de la intensa actuació política que, durant els primers anys de la dècada dels seixanta, duia a terme pertot: París, Londres, Nova York, Washington, Mèxic DF... (c. 2, 3 i 5 ). Altres cartes eren més marcadament de circumstàncies: Tarradellas compartia amb Xirgu l'anhel de veure alliberada la pàtria amb motiu de la commemoració, el 14 d'abril de 1961, del trentè aniversari de la Segona República espanyola (c. 6), o, amatent, li expressava el suport moral per la intervenció quirúrgica que l'actriu havia patit el 10 de desembre de 1962 (c. 9).

Sens dubte, el document més rellevant de l'epistolari Tarradellas-Xirgu és la missiva «estrictament confidencial» del 4 de juliol de 1960, que amb retocs també van rebre altres destinataris, com els mateixos Cuatrecasas o Cunillera (c. 4). ${ }^{26}$ Amb paraules molt sentides i un punt ditiràmbiques, el president a l'exili es condolia per la mort inesperada, el 28 de juny de 1960, a cinquanta anys acabats de fer, de l'historiador Jaume Vicens Vives, i confessava a Xirgu que la seva pèrdua tenia una repercussió molt gran en la política d'establir contactes i relacions que, la tardor de 1959, havia intensificat amb personalitats catalanes de l'interior. A partir d'aleshores, Tarradellas ja no podia comptar amb l'ajut i la mediació de l'autor de Notícia de Catalunya: havia perdut l'home que començava a ferli de pont a l'interior - $c f$. les c. 2 i 3 - per tal de crear un equip de treball que endegués la transformació política, social i econòmica de Catalunya cap a la democràcia i que, de més a més, li facilitava els enllaços internacionals i la mediació per obtenir suports econòmics. Havia de començar, com aquell que diu, de cap i de nou per poder ampliar el radi d'acció de la Presidència de la Generalitat entre els nuclis resistents de Catalunya. ${ }^{27}$

26 Tarradellas també féu arribar aquesta carta del 4 de juliol de 1960 al periodista i polític valencià Carles Esplà. Vegeu Pedro L. Angosto \& Julia Puig, ed., Carles Esplà, un periodista republicà. Cròniques, conferències i correspondència amb Tarradellas (València: Universitat de València, 2007), 199-203. És reproduïda a Cristina GATELL \& Glòria SOLER, Amb el corrent de proa. Les vides polítiques de Jaume Vicens Vives (Barcelona: Quaderns Crema, 2012), 646-649.

27 És sabut que, d'ençà del 1957 i especialment de la tardor de 1959, Tarradellas mostrà un gran interès polític per consolidar una relació fluïda amb Vicens, un home ben preparat i ben connectat amb sectors influents de la societat catalana, que podia fer-li d'interlocutor a l'interior. Vegeu, sobre 
No deixa també de tenir interès la lletra del 15 d'abril de 1961, en què Tarradellas remet a Xirgu — com també ho féu a Cunillera - una missiva de Juli Just, vicepresident i ministre de l'Interior i de l'Exili del Govern de la República espanyola, datada a Saint-Martin-le-Beau el 13 d'abril d'aquell any (c. 7). A més de comentar-li'n el contingut, Tarradellas manifestava les divergències que el separaven dels dirigents republicans espanyols i, en contra dels qui apellaven per la restauració monàrquica, feia professió de fe republicana. En la lletra a Just, també conservada a l'AMTM, Tarradellas justificava la seva negativa a participar en els actes organitzats pel Govern de la República espanyola a l'exili, al voltant de l'aniversari de la proclamació de la República el 14 i 17 d'abril d'aquell any:

Em sembla que, després de vint-i-un anys d'exili i davant la greu situació que ens trobem, ja ha arribat l'hora de deixar de celebrar públicament tants aniversaris i commemoracions, i crec que seria més eficient, i tothom ho entendria, que aquestes diades fossin de recolliment per tal de pensar i treballar més amb el present i en el futur. [...] Per altra banda, no fóra lleial, a la representació que ostento ni a mi mateix, si no aprofités aquesta avinentesa per a manifestar-vos la meva disconformitat amb certes actituds i declaracions preses i fetes per les institucions de la República. [...] Ja sabeu quines han estat i són les meves relacions amb elles. Cordials, però, sense exagerar, podríem dir que ens ignorem, car les nostres inquietuds són diferents, les nostres ambicions no són oposades, però tampoc no coincideixen massa. [...] Si tots els pobles espanyols estan adelerats per a alliberar-se del règim a què estan sotmesos, Catalunya, que ja sabeu com i de quina manera paga la seva fidelitat a la República, sent amb més neguit que ningú l'anhel de viure amb pau i llibertat. Però els nostres fervorosos delers $\mathrm{i}$ la fidelitat a uns ideals, per als quals durant mig segle el nostre poble tants sacrificis ha fet per a defensar-los, no em poden impedir que us manifesti el meu disgust o tristesa davant d'un estat d'esperit del

la relació entre Tarradellas i Vicens, Josep M. MUÑoz I LLORET, Jaume Vicens i Vives (1910-1960). Una biografia intellectual (Barcelona: Edicions 62, 1997), 348-350; Francesc BONAMUSA, «El president a l'exili», dins Jordi CASASSAS \& Carles SANTACANA, ed., Josep Tarradellas o la reivindicació de la memòria (1899-1988) (Lleida: Pagès, 2003), especialment les pp. 159-160; Oriol Malló Vilaplana, Tarradellas. Un segle de catalanisme (Barcelona: Planeta, 2003), 129-197; Cristina GATELL \& Glòria SolER, «Jaume Vicens i Josep Pla, homenots polítics», L’Avenç 358 (juny 2010): 40-48; Jesús Conte, Tarrade llas, testigo de España (Barcelona: Destino, 2011), 96-99 i 154-156, i GATELl \& SOlER, Amb el corrent de proa, especialment les pp. 422-426, 531-552 i 562-568. 
republicanisme espanyol que, sovint, dóna la sensació, almenys aquest és el meu sentiment, que no fa cap esforç per a comprendre el que passa a Espanya, i que avui el món gira al voltant d'uns problemes, d'unes inquietuds i d'unes esperances les quals les nostres velles concepcions hi tenen ben poca plaça.

En darrer terme, també té una significació destacable la carta del 17 de desembre de 1962, en què, com acostumava a fer amb els destinataris del seu cercle confidencial, Tarradellas defensava a tort i a dret la seva actuació política (c. 8). Després d'opinar que la dictadura franquista es consolidaria encara més internacionalment, es reafirmava en l'eficàcia de les accions que havia emprès a l'interior i a l'exili i, de manera implícita, insistia en la tesi - fonamental en el seu ideari- que calia situar la presidència de la Generalitat com a epicentre de la continuïtat històrica i de la unitat antifranquista dels catalans. Amb les allusions velades als sectors que qüestionaven la seva política, pecaven d'eufòries excessives o feien concessions inadmissibles, Tarradellas apuntava sobretot contra l'entusiasme, al seu entendre contraproduent, que havia causat el resultat del congrés que el Moviment Europeu organitzà a la ciutat de Munic el juny de 1962 i que el govern franquista batejà amb el nom delirant de «contubernio». Tot i que fou una de les iniciatives de més projecció exterior de l'oposició al franquisme, la tingué per una acció políticament negativa, en minimitzà l'abast i les repercussions internacionals, i la vituperà sense remissió, considerant-la als antípodes de la línia de «disciplina catalana» marcada per la Generalitat. ${ }^{28}$

En tot cas, actuant com si darrere d'ell hi hagués tot un ampli cos diplomàtic al servei d'una Generalitat de Catalunya pletòrica de recursos i mitjans, Tarradellas suplia la manca d'un servei de premsa amb els Informes confidencials que, multicopiats, enviava a nombrosos destinataris, d'una banda, i la inexistència d'un cos d'ambaixadors amb els viatges i els contactes a Europa i a Amèrica en què multiplicava les entrevistes, les converses i els contactes, de l'altra. D’aquí ve la importància que atorgava a les delegacions com a enllaços per bastir un teixit de connexions que li permetés de fer-se present entre els catalans de l'interior i de l'exili i, tant

28 Vegeu Udina, Josep Tarradellas, l'aventura d'una fidelitat, 302-304, i Josep BenET, El president Tarradellas en els seus textos (1954-1988) (Barcelona: Empúries, 1992), 79-81 i 85-97. 
com pogués, (r)establir-hi la seva molt controvertida «força moral». O dit d'una altra manera: calia fer el que calgués, a dins o fora de Catalunya, per aconseguir o consolidar una legitimitat presidencial en la corda fluixa. Xirgu era, al cap i a la fi, una peça més, de caràcter més simbòlic que influent val a dir-ho, d'aquest ordit de relacions.

Sigui com vulgui, mercès a les cartes i els informes confidencials que li remetia Tarradellas i, especialment, a la relació amical amb el doctor Cuatrecasas, Xirgu estava al dia de l'evolució de la política catalana a l'exili, que seguia amb atenció i interès des del seu refugi de Punta Ballena. Sengles cartes de Cuatrecasas a Tarradellas, la primera des de Buenos Aires i la segona des de Punta Ballena, així ho proven:

Us recordem tots els dies amb la Margarida Xirgu i no cal dir que amb tots els de casa. Seguim amb creixent esperança els aconteixements del món. Per tot arreu sorgeixen fets que condemnen públicament els dictadors. Tot fa pensar que el clima democràtic internacional es va imposant. (7 de febrer de 1960)

Des d'aquesta roca viva de la Ballena, entre la boscúria i la mar, recordem a Catalunya i també a vós. La Margarida ha llegit el vostre missatge amb gran profit. ${ }^{29}$ Li ha agradat molt. (18 de febrer de 1962)

29 Vegeu Josep TarradelLas, «Missatge de l'Honorable president de la Generalitat al poble de Catalunya», Butlletí d'Informació de la Generalitat de Catalunya [París], editat pel Servei d'Informació i Publicacions de la Generalitat de Catalunya «en terres d'exili», (des. 1961): 1-8; publicat també a Catalunya [Buenos Aires] 97 (gen.-feb. 1962): 3-6. Entre altres aspectes, Tarradellas hi feia una defensa aferrissada de la Generalitat de Catalunya a l'exili com a expressió de la «voluntat nacional» dels catalans («els homes i les seves organitzacions neixen i moren, però els pobles i les seves institucions, a desgrat de tots els daltabaixos, sempre sobreviuen com un testimoni de la seva perennitat»; «avui és un símbol i demà una realitat»), hi reclamava que, fos quin fos el règim que s'establís després del franquisme, els catalans havien de mantenir aquesta institució com a «únic interlocutor vàlid» $\mathrm{i}$ com a gresol de voluntats, i hi advocava per una reconciliació entre Espanya i Catalunya en què els catalans reivindiquessin els seus drets, però sense plantejar-ne de nous. D’altra banda, pel que fa al règim polític que s'instaurés després de la dictadura, creia que s'equivocaven els que eren partidaris de la reinstauració borbònica: «Haurien d'adonar-se que aquest ja està condemnat abans de la seva instauració, car ha estat i és un apèndix del franquisme i, per tant, no té, ni pot tenir, cap prestigi, ni despertar cap confiança a la immensa majoria del país. | A més, nosaltres hem de tenir present que la monarquia que respectava les nostres institucions ja fa segles que ha desaparegut i la dels altres ha estat sempre contra el nostre poble i els seus drets. No tenim cap motiu per dubtar que els Borbons d'ara no facin el mateix que els seus avantpassats. És per això que estic plenament convençut que Catalunya, de la mateixa manera que unànimement l'any 1931 va proclamar i acceptar el règim republicà, ho farà també el dia que expressi la seva voluntat». Així i tot, opinava que, si els espanyols 


\section{Compromís amb la catalanitat exiliada}

Encara que sigui en una dimensió de caràcter eminentment honorífic, el fet que Xirgu s'impliqués en la Delegació de la Generalitat a l'Uruguai és una prova més del vincle continuat que va establir amb l'exili català. Sigui per la relació que mantenia amb alguns dels seus amics conterranis, sigui per la bona sintonia que hi hagué amb el president Tarradellas, sigui perquè en el fons vivia la catalanitat com a dona i com a artista, sigui per tot una mica, allò que la documentació que editem ens permet de verificar és que Xirgu no renuncià a assumir la representació que li fou encomanada, ni tampoc s'inhibí a l'hora de signar documents exposats que la situaven en el costat dels vençuts. És una evidència més del seu compromís amb la catalanitat, perfectament conseqüent amb el seu republicanisme.

Arran de la mort de l'actriu, el 25 d'abril de 1969, Miquel S. Cunillera adreçà una carta a Tarradellas, datada a Andorra - la seva nova residència - el 7 de maig d'aquell any, en què es queixava de les falsedats que la intellectualitat afecta al règim franquista havia escrit sobre la finada. Tot enviant-li una còpia d'una emotiva lletra que havia rebut d'Ángel Curotto, ${ }^{30}$ hi aprofitava l'avinentesa per recordar la implicació de Xirgu en la delegació que presidí i el seu prestigi a la república democràtica de l'Uruguai:

optaven per la monarquia, els catalans no s'hi podien oposar, sinó que havien de respectar la voluntat majoritària.

30 El director d'escena uruguaià Ángel Curotto, en la seva carta a Cunillera, datada el 29 d'abril de 1969, quatre dies després de la mort de Xirgu, li confessava la seva pena per la pèrdua de «Margarita» ("Qué tristeza y qué dolor! Quince días de internación en el Sanatorio Larghero, una operación de vientre - tumor en los ovarios - y a las veinte y cuatro horas un colapso cardíaco... y terminó su vida») i el ressò que havia tingut a tot Amèrica llatina («Puede imaginar la trascendencia que la noticia tuvo en toda América. Una página entera en La Nación y así por el estilo»), com també el caràcter marcadament catalanista que prengué el seu sepeli multitudinari, un aspecte que no passà per alt a Cunillera: «Hubo muchos discursos, entre ellos uno magnífico por su emoción y significación del doctor Cuatrecasas y otro de un representante de la familia García Lorca. Sus restos bajaron a tierra envueltos en la bandera de Cataluña, mientras un catalán que había llevado al cementerio un grabador hizo oír desde lejos tan solo unos instantes la voz de Margarita en unas frases poéticas. Fue una nota que apretó a todos la garganta. Le comunico también que, antes de cerrar su féretro, se cubrió con tierra de Cataluña su mortaja, tierra que trajo un amigo de Cuatrecasas. Además des de su vela torio hasta su sepelio, el cortejo fue acompañado y presidido por un grupo de jóvenes ataviados con los trajes típicos catalanes y su estandarte al frente». 
Crec que valdria la pena que, com ell demana [Ángel Curotto], i per sortir al pas de tantes «cursileries» com s'estan escrivint sobre la nostra estimada pels soi-disants intellectualoides aburgesats, i molts fins i tot incensaris del règim, als quals tu tan bé has desemmascarat en les teves lletres, que sàpiguen quina ha estat la dignitat dels seus darrers anys, amb la seva representació de la Generalitat a l'Uruguai (i que sàpiguen que encara que facin veure que no se'n recorden aquesta segueix existint, gràcies al teu sacrifici i al de la Xirgu i de tants altres), i que acollida amb la simpatia de tot un país tan democràtic com l'Uruguai, dretes i esquerres tots la mimaven, com així mateix, uns i altres també estan amb les nostres realitats, honorant al nostre President-Màrtir, amb la plaça que porta el seu nom..$^{13}$

Des de Buenos Aires, Cuatrecasas també va escriure a Tarradellas, el 8 de maig de 1969, per assabentar-li de «la desgraciada pèrdua de la nostra Margarida Xirgu» i per explicar-li el zel que tingué a imprimir de catalanitat el sepeli de l'actriu a Montevideo, bo i fent-hi tan present com fos possible la representació de la Generalitat a l'exili:

L'enterrament va ésser una manifestació austera i sentida de dol per tot l'Uruguai. El fèretre [fou] cobert amb una bandera catalana; jo vaig fer posar des del primer moment un ram d'orquídees en nom de la Generalitat de Catalunya, damunt de la bandera. Així fou enterrada al cementiri de Montevideo. El Centre Català de Montevideo estava representat pel president i mitja dotzena de joves i noies amb trajos catalans portant el pendó del Centre Català. A l'hora de despedir el dol, jo vaig parlar primer en nom de Catalunya, dels catalans de tot el món, és a dir, en nom de lo que la Generalitat representa.

\section{Nota a l'edició}

Les cartes que editem de Josep Tarradellas a Margarida Xirgu es troben dipositades en el fons Margarida Xirgu de l’Arxiu Montserrat Tarradellas

31 La plaça Lluís Companys fou inaugurada a Montevideo el 1944, en el marc d'un dels actes més destacats del Casal Català d'aquesta ciutat: l'homenatge al president afusellat pels franquistes que fou promogut pels regidors de nissaga catalana César Batlle Pacheco i Joan Maglia, amb motiu del qual s'inaugurà un monument allusiu, obra de l'escultor Joan Serra. Vegeu l'annex 9. Com la plaça, el monòlit (i la placa commemorativa) a què es fa referència encara existeixen en l'actualitat. 
i Macià (AMTM) del Monestir de Santa Maria de Poblet. Les hem ordenades cronològicament. Com que n'hem abordat una contextualització i una lectura en aquest estudi previ, ens limitem a aclarir en nota a peu de pàgina només aquelles allusions concretes - sobretot polítiques- que s'hi fan.

Per a l'anàlisi de les cartes, hem consultat també una sèrie de documentació, dipositada a l'AMTM, que ens ha permès de desxifrar-ne millor el contingut: 1) els papers relatius a les delegacions de l'Uruguai i l'Argentina; 2) la correspondència del president amb Miquel S. Cunillera, Josep Roig i Vidal, i Juli Just, i 3) els Informes confidencials i els exemplars del Butlletí d'Informació de la Generalitat de Catalunya, editat a París pel Servei d'Informació i Publicacions de la Generalitat de Catalunya.

En l'apèndix, a més de l'article de Josep Pla a Destino que es troba en l'expedient de Margarida Xirgu, hem aplegat — seguint també l'ordre cronològic - una tria significativa de la documentació oficial de la delegació de l'Uruguai: els nomenaments dels càrrecs i la correspondència enviada per aquest organisme.

Pel que fa als criteris d'edició, tant en les cartes com en els documents de l'apèndix, siguin en català o en castellà, hem regularitzat la puntuació, l'ús de majúscules i minúscules i l'ús de les cometes i la cursiva, i hem corregit també els errors tipogràfics, ortogràfics i morfosintàtics per tal de facilitar-ne al màxim la lectura. Hem transcrit entre claudàtors els mots que apareixen impresos.

Aprofitem l'avinentesa per agrair novament a Montserrat Catalán i Benavent, directora de l'AMTM, l'amabilitat i la gentilesa dispensades en les nostres recerques, i també les atencions rebudes de Rosa $\mathrm{M}$. Brull Badia i Judith Poblet Mallafré, documentalistes de l'arxiu. D'altra banda, fem constar el nostre deute amb l'imprescindible Diccionari dels catalans d'Amèrica, en quatre volums, dirigit per Albert Manent (Barcelona: Comissió Amèrica i Catalunya, Generalitat de Catalunya, 1992). 
Saint-Martin-le-Beau (Indre-et-Loire), 8 d'abril de 1960

Senyora Margarida Xirgu

Presidenta de la Delegació de la Generalitat de Catalunya a l'Uruguai Montevideo

Distingida presidenta i benvolguda amiga,

El delegat especial, el senyor Miquel S. Cunillera, m'ha enviat l'acta de constitució de la Delegació de la Generalitat i permeteu-me que us expressi, una vegada més, el meu sincer agraïment per haver acceptat de presidir-la. ${ }^{32}$

És un gran honor que ens feu amb la vostra patriòtica determinació d'ajudar a les nostres tasques encaminades a possibilitar la llibertat de Catalunya. Estic segur que el vostre gran i ben merescut prestigi, no solament entre els catalans, sinó també estimat i admirat per altres pobles; la vostra vida al servei d'un art i d'uns sentiments, que tant us honoren, seran un estímul constant per a tots aquells que lluitem per al triomf dels nostres ideals. Per això, us dic de nou moltes gràcies i que els encerts que tots plegats aspirem a obtenir ens portin la llibertat, la pau i el benestar.

Em plau dir-vos que segurament als voltants del 20 del present aniré als Estats Units. Al seu dia us informaré detalladament del resultat d'aquest meu viatge.

Mentrestant, rebeu, benvolguda amiga, els meus millors sentiments i les meves més cordials salutacions,

Josep Tarradellas

32 Vegeu l'annex 6. 


\section{[EL PRESIDENT DE LA GENERALITAT}

DE CATALUNYA]

París, 26 d'abril de 1960

Senyora Margarida Xirgu

Presidenta de la Delegació de la Generalitat de l'Uruguai

Montevideo

Distingida senyora presidenta i amiga,

Espero que haureu rebut els Informes confidencials dels 30 de març i 14 d'abril. En el primer, em permetia dir-vos que els dies 16 i 17 rebria diferents personalitats del nostre país, acompanyats de dues de les persones més rellevants de la nostra terra avui i que resideixen a Madrid, per tal d'estudiar i redactar d'una manera definitiva el Memoràndum que deu ésser la base de les meves entrevistes als Estats Units. ${ }^{33}$

Em plau dir-vos que tot ha ocorregut tal com haviem previst i durant tres dies vàrem poder realitzar una tasca que m'omplena d'optimisme davant de les converses plenes de responsabilitat que espero podré portar a cap ben aviat.

Era la meva intenció, tal com us vaig anunciar, d'enviar-vos un Informe confidencial donant-vos compte de tot aquest resultat i d'altres visites rebudes també aquests darrers dies, però us demano que tingueu la bondat d'excusar-me que no ho faci avui, perquè, francament, em manca el temps material per a poder-ho realitzar. En efecte, des de fa quatre

33 L'Informe confidencial del 30 de març de 1960 feia allusió, efectivament, a les converses que, en l'exili francès, tingué Tarradellas amb persones de l'interior per a la redacció definitiva del Memoràndum que havia de lliurar al Departament d'Estat dels EUA. Segons apunta Malló, «Tarradellas, invitat pel Departament d'Estat a visitar els EUA el maig de 1960, vol que els assessors de Vicens l'ajudin a preparar dos memoràndums sobre la situació política i econòmica de Catalunya, basant-se en in formació veraç i dades objectives, amb els quals Tarradellas tractarà d'impressionar els buròcrates de Washington i donar per fet que tota acció a Espanya ha de tenir en compte les opinions de la Generalitat i dels seus homes a Catalunya» (Malló, Tarradellas. Un segle de catalanisme, 133). En canvi, l'informe del 14 d'abril del mateix any estava dedicat, bàsicament, a la commemoració del 14 d'abril, «diada d'afirmació dels nostres ideals nacionals i per tant republicans i del que volem ésser». 
dies, em trobo a París on he tingut diferents reunions amb totes aquelles persones que, com ja sabeu, considero les més rellevants de la collectivitat catalana i que, pel seu patriotisme i fidelitat a Catalunya, mereixen la meva confiança.

Com és natural, hem parlat extensament d'aquests problemes, de la mateixa manera que ho vaig poder fer amb diferents personalitats catalanes que resideixen al sud de França, amb motiu del meu viatge a PortVendres, que tingué lloc a darreries del mes passat.

Ja veieu, doncs, que la preparació d'aquest viatge em dóna un treball molt intens i, com us deia abans, m'heu d'excusar que no us doni avui el detall dels bons resultats obtinguts en els treballs preparatius de les converses que em penso poder portar a cap als Estats Units.

Sapigueu que sortiré de París el dia 30, si no hi ha cap entrebanc, per arribar a Nova-York el mateix dissabte vinent. A aquesta ciutat, penso romandre-hi tres o quatre dies per tal de realitzar diferents visites i, després, em dirigiré a Washington. D’aquesta capital, faré tots els possibles per a enviar-vos uns mots donant-vos la meva primera impressió.

La meva estada als Estats Units durarà, màxim, quinze dies, i no cal dirvos que al meu retorn sereu àmpliament informada del resultat de la mateixa.

Us prego que, una vegada més, vulgueu acceptar el meu profund agraïment per la vostra opinió i consell, com també pel vostre encoratjament que m'han servit, em serveixen i em serviran en aquesta tasca de la qual cada dia que passa em sento més convençut pels resultats falaguers que augmenten constantment. Totes les noves que arriben de Catalunya ho confirmen, i us asseguro que tot això m'esperona encara més per a treballar junt amb vosaltres i tots aquells catalans de casa nostra que no han perdut la fe, per tal de veure el triomf dels nostres ideals.

Us agrairé que, de part meva, vulgueu saludar a tots els catalans que us ajuden en les vostres tasques i treballs i vós rebeu, estimada amiga, una respectuosa abraçada del vostre,

Josep Tarradellas 
Saint-Martin-le-Beau (Indre-et-Loire), 8 de juny de $1960^{34}$

\author{
Senyora Margarida Xirgu \\ Montevideo
}

\title{
Distingida presidenta i benvolguda amiga,
}

Des de fa uns dies que sóc de nou aquí, després del meu viatge pels Estats Units i Mèxic. Aquest viatge ha durat un mes i em plau manifestar-vos que el resultat del mateix crec que ha estat i serà ben útil per a la realització dels nostres ideals i anhels. 35

Amb el present, us acompanyo un Informe confidencial que fa referència a la meva visita a Washington i altres problemes interessants de les nostres activitats. ${ }^{36}$ Us prego que em vulgueu excusar que no tingui l'ex-

34 L'endemà, el 9 de juny de 1960, el president Tarradellas envià també una lletra en uns termes molt semblants, datada a Saint-Martin-le-Beau (Indre-et-Loire), a Miguel Ortín, el segon marit de Xirgu: «De nou a casa, després del meu viatge als Estats Units i Mèxic, em plau saludar-vos ben cordialment i manifestar-vos que el resultat del mateix ha estat ben encoratjador per a totes les tasques que tenim el deure de realitzar. | Voldria que, en rebre la present, tant la vostra esposa com vós mateix estiguessin bé i que tinguessin la bondat d'acceptar una respectuosa abraçada del vostre amic, | Josep Tarradellas».

35 La versió oficial era aquesta: «El president Tarradellas efectuà en el curs del mes de maig el seu anunciat viatge als EEUU, per tal de correspondre a la invitació del Departament d'Estat del Govern d'aquest país. | Durant la seva estada a Washington, l'Honorable President de la Generalitat conversà amb tres dels principals collaboradors del senyor [Christian] Herter. Podem resumir el resultat d'aquestes entrevistes amb les pròpies paraules del president a un periodista del diari Novedades de Mèxic: "Puc afirmar que les converses que he mantingut i les informacions que he manifestat seran útils a la causa de la República espanyola." | El dia 15 de maig aterrava a Mèxic per tal d'entrevistar-se i informar els diputats de la Diputació Permanent del Parlament de Catalunya. | Durant la seva estada a Mèxic l'Orfeó Català li ofrenà un Vi d'honor que es veié concorregudíssim. | El dia 29 de maig el president Tarradellas es trobava de retorn a França», «El viatge del president Tarradellas a Washington i Mèxic», Butlletí d'Informació de la Generalitat de Catalunya [París] 26 (jul. 1960): 4.

36 L'Informe confidencial del 8 de juny de 1960 anunciava el propòsit de Tarradellas d'enviar una síntesi de les gestions fetes als Estats Units d’Amèrica («principalment de les entrevistes celebrades amb el Departament d'Estat d'aquest país»). Avançava també la seva satisfacció pel resultat de l'estada que hi féu i les converses que hi establí: «vaig entrevistar-me diferents vegades amb les persones més significades de la diplomàcia nord-americana, la responsabilitat de les quals fa referència a Europa i d'una manera especial a Espanya, França i Portugal. Em sembla que el canvi d'opinions que vam efectuar i l'estudi d'informacions que teníem uns i altres permetran nous contactes que poden ésser ben fructuosos pels nostres anhels». Així i tot, el president Tarradellas no creia que aquestes converses servissin per fer canviar la política nord-americana en relació amb el general Franco. 
tensió que jo voldria, i això és degut al fet que abans he cregut necessari parlar amb els representants de la Generalitat a casa nostra i que veuré la propera setmana en una ciutat del sud d'aquest país. Però us puc assegurar que, abans de fi de mes, tindreu àmplia informació no solament del resultat de totes les meves gestions, sinó també de la situació en què es troba actualment Catalunya. Una cosa i altra em permet manifestar-vos que tinc el ple convenciment que estem en el bon camí per obtenir resultats positius i que no fóra res d'estrany que aquest any veiéssim, per primera vegada, com va endavant un pensament i una acció que està feta de patriotisme i de bon seny.

Amb l'amistat de sempre, us prego, benvolguda amiga, que rebeu els meus millors sentiments,

Josep Tarradellas 
Saint-Martin-le-Beau (Indre-et-Loire), 4 de juliol de 1960

\author{
Senyora Margarida Xirgu \\ Presidenta de la Delegació de la Generalitat de Catalunya de la República \\ Oriental de l'Uruguai \\ Montevideo
}

\title{
Distingida presidenta i benvolguda amiga,
}

Tinc el sentiment d'informar-vos que el dia 28 del mes passat morí a Lió (França) l'eminent professor de la Universitat de Barcelona, senyor Jaume Vicens i Vives. La seva personalitat com a historiador i investigador depassa les nostres fronteres i, com molt bé s'ha dit aquests dies, era un català universal. La seva obra ha assenyalat un camí que marcarà profundament l'actual generació que està formada per unes inquietuds i uns delers de conèixer i d'actuar que forçosament serà la que donarà a Catalunya el ressorgiment que tots anhelem. En aquesta carta, no ve molt a propòsit exposar-vos la seva obra immensa i la repercussió que aquesta ha tingut i tindrà. És per informar-vos d'aquesta malaurada pèrdua que ha tingut la nostra pàtria i el seu profund dolor que voldria compartíssiu tots els catalans.

Un gran poeta de casa nostra ha dit, aquests darrers dies, que la pèrdua del professor Jaume Vicens i Vives era una catàstrofe pel nostre poble. ${ }^{37}$

37 Josep Maria de Sagarra, en l'esplèndida necrològica dedicada a Jaume Vicens Vives, considerava efectivament que la seva pèrdua havia estat «una auténtica catástrofe». Val la pena de reproduir el context genèric en què s'inscriu aquesta valoració de l'autor de Vida privada: «En los funerales, no en los concretos y litúrgicos, sino en esos funerales invisibles, a veces fugaces, a veces persistentes y profundos, que se producen en la conciencia colectiva ante la desaparición de un hombre memorable, quisiera marcar yo los puntos esenciales para limitar el contorno intelectual y humano de Vicens Vives, de manera que en la reflexión de mis coetáneos, esta forzada y cruelmente injusta desaparición de tan ilustre elemento, se proyecte como una auténtica catástrofe en la realidad presente y en las futuras posibilidades de la existencia espiritual de nuestro país. | Si atendiéndome a nuestra vida cultural, hablo aquí de catástrofe, no creo exagerar, ni hinchar la emoción ante una irreparable desgracia; no andamos en nuestro momento catalán muy ricos de positivos valores, para dejar de ver cuántos puntos de eficacia se sumaban en la persona de Vicens Vives, ni cómo, su figura eminente, represen taba algo excepcional y único entre los de su clima y de su generación. [...] Este excepcional científico era el tipo de hombre público, que sin alcanzar una gran publicidad, podría ser de la máxima eficacia en determinados momentos nuestros. Vicens Vives era el más adecuado catalán para la Cataluña 
No solament coincideixo plenament amb aquesta afirmació, sinó que em sembla que encara ho és més del que ell pugui creure. Catalunya perd un dels seus fills més eminents i també un lluitador amarat de catalanitat i d'un esperit de combat que, en aquests darrers anys, indiscutiblement s'havia posat a la direcció i a l'avantguarda de tots aquells que aspiren a la llibertat del nostre poble. Puc afirmar-vos que tots els moviments de protesta no específicament obreristes que s'han produït a Catalunya, han nascut o han estat influïts d'una manera poderosa per l'alta personalitat i prestigi que irradiava del professor Jaume Vicens i Vives. A la Universitat, als instituts, a les escoles, amb els seus equips d'investigació, etcètera, etcètera, per la seva constant i fervorosa acció havia realitzat una tasca que dissortadament no podem manifestar, però estic segur que un dia vindrà en què tot Catalunya li farà l'homenatge que es mereix i, d'aquesta manera, el seu nom serà, en tots els ordres de la nostra vida nacional, un exemple a seguir per aquells que aspirem a veure la nostra pàtria lliure, pròspera i que, per tot arreu, mereixi el respecte i admiració.

Segurament, si heu llegit o penseu fer-ho, la premsa de Barcelona i de Madrid, us estranyarà extraordinàriament tot el que acabo de manifestar-vos, car aquella ha omplenat d'elogis el professor Jaume Vicens i Vives i, és clar, tot el que us expresso forçosament haureu de trobar-ho incomprensible. Per aclarir-ho, em permeto dir-vos, en poques paraules, un aspecte de la vida d'aquest gran català, conegut per ben pocs i us demano que vulgueu considerar-ho com a estrictament confidencial.

En l'Informe que us vaig enviar el mes de novembre de l'any passat, ${ }^{38}$ us deia que donava per acabades les converses que, durant els mesos de setembre i octubre, havia tingut amb diferents personalitats de Catalu-

de hoy, y no creo equivocarme al adivinar en él una de nuestras más valiosas reservas», José María de SAGARRA, «Un catalán universal», La Vanguardia Española, 29 juny 1960, 5.

38 A més de detallar els darrers viatges i contactes que havia mantingut a Europa i Amèrica, en l'Informe confidencial del 19 de novembre de 1959 Tarradellas exposava la seva «profunda i trista sorpresa» envers els signants del Pacte de París i també envers els promotors de l'operació frustrada, l'estiu de 1959, de convocar eleccions presidencials i de proposar-hi la candidatura de Pau Casals per rellevar-lo al capdavant de la Generalitat. No s'estava, així mateix, d'arremetre contra el Consell de les Forces Democràtiques de Catalunya i altres organitzacions que s'arrogaven, al seu parer injustament, la representativitat del país. De fet, qualsevol intent dels partits o organitzacions indígenes d'incorporar-se a plataformes unitàries de disciplina no exclusivament catalana — fou el cas del Pacte de París de 1957 - va merèixer la repulsa oficial del president Tarradellas que, sense ambages, n'anatematitzava els promotors per la deslleialtat a Catalunya i la claudicació dels ideals nacionals. 
nya. Aquestes converses, per tot el que ha anat succeint, ja us haureu donat compte que varen tenir un resultat positiu. Doncs bé, la persona que va possibilitar establir nous contactes, desfer equívocs, possibilitar enteses, crear un ambient de comprensió i de concòrdia i que acabà per ésser dintre de Catalunya un defensor de les nostres institucions, cosa que fins llavors no havia fet, fou justament el professor Jaume Vicens i Vives. Però no en tingué prou amb això, sinó que el seu prestigi i la seva influència, des del meu retorn del viatge que vaig fer a Amèrica l'any passat, el posà molt sovint a la difusió i a la defensa d'uns sentiments que són els que nosaltres sempre hem defensat. La seva actitud, després de les llargues converses que tinguérem i que ja he referit, causà una gran impressió a tots aquells que no havien compartit el nostre pensament i el perquè de certes posicions preses. És a dir, Jaume Vicens i Vives és l'home que fa possible per primera vegada, d'una manera seriosa i plena de responsabilitat, que s'estableixi entre l'interior i nosaltres una estreta comunitat de sentiments i de desigs que porta per conseqüència el meu optimisme que, des de fa un temps, us he anat exposant. És gràcies a ell que foren possible les diferents reunions que, en aquests darrers anys, he tingut en diferents llocs de França i Suïssa. És ell qui possibilità els contactes i els Informes que permeten el meu viatge als Estats Units, parlar de la situació interior d'Espanya d'una manera que féu gran impressió. En fi, fóra no acabar mai, si jo us tingués de dir, ara, tot l'agraïment que li dec. Comprendreu, doncs, el perquè considero la seva pèrdua com un desastre, car el lloc que ocupava és, almenys, ara per ara, impossible d'omplenar.

Em permeto assenyalar-vos que, si us dic tot això, que és ben trist, però també ben encoratjador, car vol dir la confiança que inspirem, és per la necessitat cada dia més imperiosa que tenim de preocupar-nos ben poc, els que estem a l'exili, davant de certes campanyes o projectes que hi poden néixer i que no tenen absolutament cap importància. A través dels diferents Informes que us he enviat, m'he permès dir-vos que mai com ara els nostres problemes havien estat en el bon camí. Us deia això perquè aquest optimisme naixia de dintre de Catalunya. És evident que la pèrdua del patriota Jaume Vicens i Vives és un cop molt dur, car m’obligarà a reorganitzar altres accions i altres contactes que, a hores d'ara, no 
preveig. La seva mort, la condemnació dels senyors Pujols i Pizón, ${ }^{39}$ les brutalitats del règim franquista i els insults prodigats constantment pels seus defensors, ens diuen que Catalunya està en el camí de la victòria. Al mateix temps, em permeto demanar-vos que tingueu la bondat de fer-me confiança, si algunes vegades, en el passat, en el present o en el futur, deixo d'informar-vos com jo voldria. Si no ho faig, no és pas per manca de confiança envers vós, sinó perquè, com no dubto ho comprendreu, les meves relacions amb Catalunya que, avui s'estenen a tots els estaments socials del nostre poble, m'obliguen a una reserva que, en certs moments, deu ésser total. Malgrat això, sapigueu que res de definitiu decidiré sense que, abans, estigueu informada per tal de conèixer el vostre consell.

Excuseu-me aquesta carta, però m'ha semblat que era completament necessari que coneguéssiu un aspecte important d'aquesta lluita secreta que cada dia s'intensificarà més i més contra la dictadura franquista. El trist és que el motiu d'haver-la fet conèixer sigui la pèrdua del millor soldat amb què comptava avui dia Catalunya. Ho crec sincerament i, en el seu dia, tots els catalans es donaran compte del perquè d'aquesta afirmació meva. En aquestes hores de profund dolor, em cap solament el consol que els dies 14 i 15 de juny vaig estar a Lió, a visitar-lo, que vàrem parlar i que el dia 25, des d'aquí, a casa, ho vaig fer de nou per telèfon. Converses totes elles que no oblidaré, car ell no creia que la seva vida estigués tan amenaçada i tot ell era una flama d'illusions per les lluites que veia venir. Tot plegat ben emocionant..$^{\circ}$

Em permeto demanar-vos, una vegada més, que vulgueu considerar aquesta lletra estrictament confidencial, car ha caigut un combatent, però en aquesta lluita, que ell tan personalment portava, hi ha encara els

39 El president Tarradellas es refereix a la detenció de l'activista Jordi Pujol i l'impressor Francesc Pizón acusats de ser els màxims instigadors dels fets del Palau de la Música, esdevinguts el 19 de març de 196o. Després de ser sotmesos a un consell de guerra, el 13 de juny de 196o, van ser condemnats a set i tres anys de presó respectivament. Vegeu Joan Crexell, Els fets del Palau i el consell de guerra a Jordi Pujol (Barcelona: La Magrana, 200o), i Xavier Polo, «Todos los catalanes son una mierda». La història d'una vida (Barcelona: Proa, 2005), especialment les pp. 145-164.

40 A la primeria de juny de 1960, Tarradellas, que havia retornat del seu viatge als EUA, telefonà a la Clínica del Parc de Lió on estava ingressat Vicens per preguntar sobre el seu estat de salut. Més tard, els dies 14-15 de juny, va visitar-lo, acompanyat de Manuel Ortínez, a la mateixa clínica, on continuava ja molt malalt. En la cerimònia fúnebre Rafael Tasis representà el president Tarradellas i fins dugué, en nom seu, un ram de flors que acompanyà el fèretre. Vegeu MuÑoz, Jaume Vicens i Vives, 348 , i GATELL \& SOLER, Amb el corrent de proa, 563-568. 
246 FRANCESC FOGUET I BOREU

seus amics, els seus deixebles i els qui, estic segur, seguiran el seu pensament i els seus ideals.

Us saluda ben afectuosament el vostre amic,

Josep Tarradellas 


\title{
Rosselló, 24 d'octubre de 1960
}

\author{
Senyora Margarida Xirgu \\ Presidenta de la Delegació de la Generalitat de Catalunya de la República \\ Oriental de l'Uruguai
}

Montevideo

\section{Distingida presidenta i benvolguda amiga, Els meus propòsits d'informar-vos, i ben àmpliament, del resultat del meu viatge als Estats Units, com també dels problemes que durant aquests darrers mesos s'han plantejat dissortadament, com ja sabeu, no m'ha estat encara possible portar-los a terme i us prego que tingueu la bondat d'excusar-me'n. ${ }^{41}$}

41 En una lletra que Lluís Gausachs, secretari general de la Presidència, envià a Margarida Xirgu, datada a Choisy-le-Roi (Seine), el 8 de setembre de 1960, s'excusava pel fet que encara no li havien remès l'Informe confidencial anunciat sobre el resultat de les gestions fetes als EUA pel president de la Generalitat i sobre les converses que mantingué a França amb diverses personalitats catalanes. Gausachs li confessava que el president havia tingut «un greu problema» en arribar dels EUA i, de resultes d'això, havia d'esmerçar els esforços a refer les «relacions amb el Govern francès», malmeses a causa de l'actuació d'alguns compatriotes: «Aprofitant una vegada més el seu viatge per Amèrica, certs catalans - sortosament pocs - residents a França havien facilitat falses informacions respecte al pensament que sempre han mantingut les institucions de Catalunya, pensament que vós coneixeu perfectament, i així aconseguiren, servint-se de mitjans que tot català repugna, que el 21 de juliol darrer el ministeri de l'Interior francès prengués una resolució en la qual es donava satisfacció a les falsedats i acusacions que aquests catalans —encegats per l'audiència cada dia més gran que van prenent les nostres institucions - havien fet arribar a les autoritats d'aquest país. | Malgrat les innombrables gestions que ha fet el president, a hores d'ara encara no s'ha pogut resoldre aquest problema, tal com ell desitja i tal com els catalans ens mereixem. [...] Això és motiu de gran preocupació i ha obligat el president a consagrar-se íntegrament a restablir les relacions que sempre havien estat cordials amb les autoritats franceses. Darrerament, ha estat deu dies a París, i crèiem i esperàvem sincerament que li seria possible obtenir el resultat satisfactori que li hauria permès dedicar-se plenament a aquest Informe confidencial que ja us ha estat anunciat en anteriors correus i donar-vos compte també de les activitats d'aquests darrers temps. Dissortadament, no ha estat així encara. El dia 14 deu tornar[-hi] de nou, i potser les altres importants entrevistes que li han estat concedides per aquesta data seran decisives. D'ésser així, com espera, les seves activitats normals reprendran el seu curs i sereu assabentat extensament de l'actual situació tant a l'estranger com a casa nostra de les institucions catalanes i dels seus treballs». En una carta posterior, del 3 de novembre de 196o, també datada a Choisy-le-Roi, el mateix Gausachs comentava a Xirgu les converses que, en territori del sud o del migdia de França, Tarradellas mantenia amb personalitats polítiques catalanes durant aquella tardor, i li anunciava el proper viatge a Londres, a mitjan novembre. 
Estic segur que haureu comprès que el meu silenci és degut a motius importants i, encara que ja sé que no en dubteu, em permeto dir-vos que tingueu la completa seguretat que, en el seu dia, us en donaré compte. Per avui, sapigueu que, durant aquest període de temps, en cap moment he deixat de complir les tasques que m'imposen els meus deures i la meva fidelitat a Catalunya.

Arran del meu viatge a Washington i a Mèxic, vaig tenir ocasió de posar-me en contacte amb una personalitat anglesa, ${ }^{42}$ la qual m'indicà la seva opinió que tal vegada seria convenient que exposés el nostre pensament a persones qualificades del seu Govern. Avui em plau informar-vos que, si no surt cap inconvenient, segurament la setmana propera aniré a Londres, on penso estar-me els dies que calguin per tal de fer conèixer quins són els nostres anhels i les inquietuds que sempre hem tingut, però principalment en aquests moments, davant de la situació internacional que és evident que, més tard o més aviat, tindrà una forta repercussió en la vida de l'actual Estat espanyol.

Fa uns dies que em trobo en aquestes contrades on he tingut diferents converses amb persones de Catalunya, l'opinió i el consell de les quals era indispensable conèixer abans d'emprendre el meu viatge. El resultat de les mateixes és ben esperançador i, per tant, ens permetrà de continuar el camí que tots plegats ens hem traçat.

Us agrairé que, de part meva, vulgueu saludar ben afectuosament tots els membres de la Delegació, i vós rebeu, benvolguda presidenta, tota l'amistat i el respecte del vostre,

Josep Tarradellas 
Saint-Martin-le-Beau (Indre-et-Loire), 14 d'abril de 1961

Senyora Margarida Xirgu

Montevideo

Distingida presidenta i benvolguda amiga,

En aquesta Diada que recordem amb emoció i fervor, em plau expressar-vos els meus sincers anhels que aviat sigui possible veure lliure la nostra pàtria.

La fidelitat que en tot moment mantenim envers la nostra Catalunya i la tasca plena de feixugues responsabilitats que tots plegats realitzem, cada dia que passa estic més convençut que és el millor camí que hem emprès i que ens portarà al triomf dels nostres ideals.

Aprofito també aquesta avinentesa per a dir-vos tot el meu agraïment per la vostra confiança i estigueu segura que, per damunt de totes les dificultats que comporta el compliment dels meus deures, faré tot el que calgui per ésser-ne avui i sempre mereixedor.

Us agrairé que de part meva vulgueu expressar aquests sentiments i les seves cordials salutacions a tots els membres de la Delegació.

Rebeu, estimada amiga, una respectuosa abraçada,

Josep Tarradellas 
Saint-Martin-le-Beau (Indre-et-Loire), 15 d'abril de 1961

Senyora Margarida Xirgu

Montevideo

Benvolguda presidenta i distingida amiga,

Em permeto adjuntar-vos còpia de la lletra que, en data 13 del corrent, he adreçat al senyor Juli Just, vicepresident i ministre de l'Interior i de l'Exili del Govern de la República espanyola.

Pels seus termes, podreu donar-vos compte que els motius que m'incitaren el darrer any a no assistir als actes organitzats pel Govern en commemoració de la proclamació de la República no han variat, ans al contrari. En efecte, la meva posició política en aquest aspecte, que ja coneixeu, no ha sofert la més lleugera rectificació, car continuen les divergències que existien amb els homes del Govern republicà a l'exili.

Però, davant de l'acció de certes organitzacions i personalitats tant exiliades com de l'interior, afavorint o intentant afavorir una restauració monàrquica, crec que tenim el deure ineludible de fer conèixer la posició de les nostres institucions i del poble català.

La meva presència a aquests actes, com ho assenyalo en la lletra, no obeeix doncs a altre objectiu que el de manifestar d'una manera clara i sense equívoc que, pel damunt de les actuacions personals o de les diferències d'apreciació, Catalunya manté la seva fidelitat republicana.

Amb l'amistat de sempre, rebeu, distingida amiga, una respectuosa abraçada del vostre,

Josep Tarradellas 
Saint-Martin-le-Beau (Indre-et-Loire), 17 de desembre de 1962

Senyora Maragarida Xirgu

Montevideo

Benvolguda presidenta i distingida amiga,

Un altre any s'acaba i la nostra Catalunya, per la força de la dictadura franquista, continua sotmesa. Per damunt de certes aparences, aquesta dictadura no minva, ans tot al contrari. Fóra un error creure que les continuades manifestacions de liberalisme, que darrerament tant prodiga el règim, són una realitat en la vida del nostre poble.

Malgrat l'acció continuada d'aquells que volen impossibilitar per la força i per la complaença d'alguns catalans la realització dels nostres anhels, Catalunya no solament es manté fidel a aquells ideals pels quals mai no ha deixat de lluitar, sinó que aviva cada dia més la seva voluntat de ferlos triomfar.

Durant aquest any s'han produilt fets d'una importància extraordinària i, si avui no és possible fer-los públics, ni preveure totes les seves conseqüències, és evident que representen el pas més efectiu i ple d'esperances positives per a realitzar una acció que sigui la veritable voluntat de tot el nostre poble.

Cada dia es veu més clar que no hi ha altra solució, per tal de portar a cap una tasca eficient, que la d'actuar a dintre i a fora de Catalunya, tenint solament present les realitats i ambicions del país i la lleialtat d'aquells que no han perdut la fe en Catalunya. Com sigui que ja coneixeu el pensament i l'acció de la nostra institució davant de certs fets produïts a l'interior i a l'exili, no és necessari avui manifestar-los novament, però sí que em permetreu constatar que, em sembla, la nostra actitud ha estat la justa. Si per un moment es vol tenir en compte com ella fou patriòtica i assenyada davant d'entusiasmes incomprensibles i que el temps, com era de preveure, ha demostrat la seva inutilitat, és innegable que el prestigi de la nostra institució i la confiança que inspira es fa més present en la vida del nostre poble. 
Certes eufòries insòlites que han expandit aquells que no volen, o no els interessa, donar-se compte de la situació de Catalunya i d'Espanya, ens obliguen a seguir el camí que ens hem traçat. Creiem que l'any que anem a començar serà encara més profitós pels nostres ideals i anhels. Tot ens diu que a casa nostra continuarà la clarificació de posicions equívoques i, per altra banda, es produirà l'eliminació espontània d'aquells que creuen que tot depèn de les genuflexions que es facin als adversaris d'avui i de demà.

Cal que siguem cada dia més exigents, no solament amb el règim franquista, sinó també amb aquells que, com ja vàrem assenyalar el 29 de maig de l'any passat, tendeixen més a impossibilitar la unitat dels catalans que a lluitar contra la dictadura. ${ }^{43}$

Per endavant em sembla, però, que serà bo de pensar que possiblement el règim franquista, gràcies en gran part a la seva acció internacional, consolidarà una mica més la seva situació economicofinancera durant l'any 1963. Es realitzi o no, cal que des d'ara tinguem present que el franquisme no resoldrà cap dels problemes vitals que té plantejats el nostre poble, i, per tant, hem de lluitar encara amb més fervor per tal de possibilitar el triomf dels nostres ideals. En cap moment hem d'oblidar que tota acció que no tingui present el conjunt dels nostres problemes i dels nostres anhels no ha de merèixer ni la nostra aprovació ni el nostre escalf.

Molt agraït de la vostra confiança, us prego que vulgueu acceptar al mateix temps els meus sincers desigs que l'any vinent us aporti totes les benaurances i entre elles la llibertat de la nostra Catalunya.

Respectuosament us abraça el vostre amic,

\section{Josep Tarradellas}

43 No hem trobat cap escrit o declaració del 29 de maig de 1961. Segurament, es tracta d'un error: Tarradellas devia voler remetre al «Missatge als delegats i a les delegacions de la Generalitat a l'interior de Catalunya i a l'exili» de l'abril de 1960, que hem escoliat a la nota 11. De tota manera, en el «Missatge de l'Honorable President de la Generalitat al poble de Catalunya», del desembre de 1961, que hem glossat a la nota 29, hi tornava a fer una crida a la unitat dels catalans a l'entorn de la Generalitat: «En tot moment sapigueu que cap poble pot assumir deures i responsabilitats, ni resoldre els seus problemes, si manca de direcció, d'unitat. No caiguem en l'error de creure que un país pot sobreviure cercant solucions fora de la seva història. La divisió, les divergències minven els drets. Si restem, doncs, fidels a nosaltres mateixos, és a dir, a les nostres institucions que ens donàrem unànimement, el triomf serà segur i esplendorós. El camí drecer de Catalunya, no en dubteu, és servar fidelitat als ideals del seu ressorgiment que culminaren amb la Generalitat», TARRADELLAS, «Missatge de l'Honorable president de la Generalitat al poble de Catalunya», 8. 
Saint-Martin-le-Beau (Indre-et-Loire), 2 de gener de 1963

\author{
Senyora Margarida Xirgu \\ Montevideo
}

Distingida senyora i benvolguda amiga,

He sabut que darrerament heu estat intervinguda, que sortosament tot ha anat bé i que ja esteu en plena convalescència. Podeu pensar com he estat content en saber el vostre restabliment. ${ }^{44}$

No cal dir-vos que desitjo de tot cor que la vostra salut vagi tal com vós anheleu, car cada dia que passa es fa més necessari que tornem i amb llibertat a la nostra Catalunya!

Us agrairé de part meva vulgueu saludar ben afectuosament el vostre espòs, i vós rebeu els millors sentiments de,

\title{
Josep Tarradellas
}

44 En una carta datada a Montevideo el 17 de desembre de 1962, Miquel S. Cunillera Rius li féu saber que «el passat dilluns 10, fou operada la nostra estimada Margarida Xirgu. La intervenció fou com a conseqüència d'una litiasi biliar i tingué complert èxit, encara que segueixi a la clínica. Les molèsties li començaren fa un any aproximadament, però darrerament s'accentuaren en forma que feren de tot punt necessari el tractament dit. Estiguérem fent acte de presència en el moment operatori, ja que per la seva edat, 74 anys, no cal dir com ens preocupava als amics. Els senyors Justino Zavala Muniz i Ángel Curotto, tant amics d'ella, i a més en Cuatrecasas i jo, a part de les respectives mullers. Ahir la vaig visitar de nou, trobant-la francament molt bé i més optimista que mai, pregant-me que et saludés». Uns dies més tard, el 31 de desembre, el mateix Cunillera li comunicava que Xirgu ja estava «completament restablerta de la seva intervenció». 
254 FRANCESC FOGUET I BOREU

$10^{45}$

Punta Ballena, desembre de 1964

Us desitgem feliç Any Nou.

Afectuosament,

Margarida Xirgu

Miquel Ortín

45 Postal nadalenca amb un dibuix allusiu signat per Marisa. 


\section{Annex}

\section{1}

\section{Margarita Xirgu}

Tenía la idea que Margarita Xirgu vivía en Chile, donde tenía una casa —que me habían descrito preciosa - situada en el llamado Barrio Alto de Santiago. Pero ha resultado que en Montevideo me he encontrado cara a cara con la que puede ser llamada — sin retoque alguno- la mayor actriz de la América Latina. Ni ella me conocía a mí, ni yo la conocía a ella físicamente. Nos conocíamos - ¿cómo decirlo? - indirectamente. Probablemente es la mejor manera de conocerse.

En los porches del Teatro Solís, de Montevideo, leí un cartel que decía que se representaba en el Parque Rivera, que es un parque de pinos situado en las inmediaciones de la capital del Uruguay, el Sueño de una noche de verano, de Shakespeare, dirigido por Margarita Xirgu. Allí me dirigí y quedé deslumbrado. Deslumbrado por la naturaleza, por la inmensa calidad de la obra, que se dió con la música que Mendelssohn escribió cuando Tieck tradujo la obra al alemán — tiempos de Goethe- y por la maravillosa representación que de la obra se hizo.

Cuando le dije a la gran actriz todo esto y muchas cosas más, haciendo un esfuerzo de memoria para recordar la correspondencia entre Schiller y Goethe, en relación con la obra de referencia, Margarita me miró bondadosamente, con una sonrisa maternal y me dijo:

\section{-Fem el que podem!}

¡Estupenda señora es Margarita Xirgu! Pequeña, nerviosa, con ojos de una vivacidad extraordinaria, trabajadora infatigable, simpática, acogedora, capaz de coger al vuelo las más sutiles finezas del espíritu, toda sensibilidad, de una raza estupenda, Margarita me dice:

-Veo que usted me mira con insistencia. Sin duda, quiere conocer mi edad. Se la voy a decir en seguida. Yo nací en Molins de Rey hace sesenta y nueve años cumplidos. Añadiré que mi primer viaje a América —vine con Emilio Thuillier - se produjo en 1913. ¿Cuántos años tenía usted entonces, amigo Pla?

-Dieciséis. 
-Yo tenía veinticinco. Era joven, usted era un niño. Ahora tiene usted los cabellos grises y yo me los tiño ligeramente de rubio. Ha pasado algo más que el sueño de una noche de verano; ha pasado el sueño de la vida. Pero, en fin, algo se ha hecho: hemos trabajado intensamente. Ya se lo decía: hem fet el que hem pogut, vet-li aquí...

¡Qué curiosa personalidad! Es una mujer que, por el mero hecho de estar en un lugar, crea a su alrededor un ambiente, un clima. Naturalísima, de una sencillez perfecta, sin rastro alguno de afectación, totalmente extraña al menor rastro de cabotinaje teatral y a lo que se presupone cuando se piensa en una actriz; hablando de una manera pausada, lenta, deliberadamente matizada y compleja, sin vanidad alguna, humilde, Margarita Xirgu, sin el menor esfuerzo, suscita permanentemente, en su contorno, un clima. Esta clase de personas son raras, abundan poquísimo. El fenómeno me atrae y se da cuenta.

-Usted me mira - me dice-, me investiga. En realidad, usted se extraña de haber encontrado precisamente aquí en América, a cinco mil millas de nuestro país, una mujer catalana de tipo - ¿cómo diré? - arcaico, situada al margen de la vida moderna en todo menos en las ideas, que le habla de trabajar, que trabaja sin parar como las mujeres de algún día, que sostiene que la seriedad es la cosa más importante de la vida...

-En efecto, señora. En estas cosas pensaba, exactamente... Compruebo, por otra parte, que su trabajo ha sido eficiente. No suele ser corriente encontrarse con una obra de Shakespeare de esta elevadísima categoría.

- Ha sido algo extraño, en efecto. Vine al Uruguay por unos días, contratada por el Teatro del Estado, por el Teatro Solís, para representar $L a$ Celestina, en el arreglo de la obra realizado por el profesor Morales, de Santiago de Chile. Y hace casi nueve años que estoy aquí. Durante este tiempo, he realizado la labor más provechosa quizás de mi vida. He dirigido la Escuela de Arte Dramático del Uruguay, he formado una gran cantidad de actores y de actrices, he creado una escuela, un gusto, una sensibilidad teatral en este país, muchos discípulos. Ya tendrá usted ocasión de saberlo, si es que tiene curiosidad por estas cosas. Hemos tratado de hacer que ocurriera algo y algo ha ocurrido, algo que ha tenido repercusión en muchos lugares de América. Hemos trabajado a favor de la calidad y no crea que el teatro sea hoy aquí improvisación, aproximación. Hoy se saben muchas cosas de teatro en estas tierras de América... 
Pero esta labor no podía durar siempre, porque fatiga. Le confieso que me convendría descansar, cosa que tampoco es fácil. Las cosas se enlazan constantemente y los compromisos se suceden...

Se comprende. No creo que exista hoy, en el entero mundo de la América hispánica, una personalidad viviente tan universalmente conocida, admirada, adorada como Margarita Xirgu. No creo que exista en ramo alguno de la actividad un caso semejante al de la popularidad de esta señora en estas tierras del continente americano. Es algo más que el respeto debido a una gran artista; es una efusión delirante de cordialidad que produce ovaciones abrumadoras en los más diversos públicos y en los más alejados países. Es un caso de unanimidad impresionante y tanto más notable cuanto que hace ya muchos años que esta señora abandonó el teatro efímero y fácil, para concentrar toda su pasión en obras antiguas y modernas de valor permanente.

- Puede uno naturalmente equivocarse - me dice la señora Xirgu-, pero costando tanto esfuerzo representar una obra buena como una cualquier vulgaridad, es preferible optar por la primera. En mi adolescencia se creía en España que Echegaray era un genio, un autor imprescindible. ¿Se da usted cuenta? Si ya entonces disentía sobre Echegaray, ahora mi experiencia me lleva a una reflexión más exigente. Mis obras de repertorio, en los últimos años, han sido Macbeth, de Shakespeare; Tartufo, de Molière; La Celestina; El alcalde de Zalamea, de Calderón; Fuenteovejuna, de Lope; El abanico, de Goldoni; El inspector, de Gogol; El soldado de chocolate, de Bernard Shaw, y obras de Jean Giraudoux (La loca de Chaillot), Thorton Wilder, Saroyan, Pirandello, el magnífico teatro de Florencio Sánchez y García Lorca, naturalmente. El éxito de Lorca en América va en aumento. Cuando lo estrené en Méjico, unas pocas representaciones bastaron. Ahora, veinte años después del estreno, tuve que dar allí Bodas de sangre durante dos meses seguidos triunfalmente. ¿Qué me dice usted del repertorio?

-Es muy bueno, pero le falta un autor.

- ¿Qué autor falta?

-Anton Chéjov.

- ¿Lo considera usted inescamoteable?

-Creo que es el autor que viene. Mejor dicho: es el autor que está ya en la puerta. En Europa, señora Xirgu, Chéjov es el autor que se represen- 
ta más del momento. Y se comprende. En Europa hay más seguridad, se come más que diez años atrás, el peligro de la guerra se ha alejado, se vive una etapa de pleno empleo. Ya conoce usted las brutalidades que se representaron y se escribieron en Europa inmediatamente después de la guerra y de los campos de concentración. Esto ha pasado ya, se ha desvanecido. El retorno al bienestar implicará la reaparición de un romanticismo, de la fiebre del ideal, de la vaguedad. Chéjov se representa hoy cada día en Milán, Zurich, París, Londres, Berlín, Estocolmo... No hay más que ver las carteleras en la prensa. Además, Chéjov es un autor para usted, señora Xirgu. Usted puede crear climas, ambientes, y Chéjov fué un creador prodigioso de ambientes.

Pero durante mi corta estancia en el Uruguay, ¿de qué no hablamos con Margarita Xirgu? Hasta hablamos de su posible venida al país, para descansar, se entiende, no como Margarita Xirgu, sino como esposa de su marido. La señora Xirgu piensa en su numerosa, excelente familia. «Me gustaría verlos a todos - me dice-, hablar horas y horas con ellos. ¡Son tan buenos! Luego me gustaría pasear por la Rambla, ir a Olot, que es tan bonito; visitar la catedral de Gerona con Pompeyo Pascual y su familia; ir a Breda, que es el país de les olles; ver el Ampurdán, el Canigó... Los paisajes, en América, son impresionantes: los Andes, el río Madalena, las selvas, Méjico... Pero nuestros paisajes hacen más compañía. También me gustaría conocer Suiza. ¿No es ridículo que yo, que conozco tantas tierras y tantos mares, no conozca Suiza? A veces, cuando estoy cansada, sueño en el maravilloso aburrimiento de Suiza, como una materialización de todas las delicias de este mundo. Amigo Pla, hemos de hablar de Suiza. Mañana venga a almorzar a casa y hablaremos de las montañas de Suiza... ¿Entendidos?»

José PLA, «Calendario sin fechas. Margarita Xirgu», Destino 1.075 (15 març 1958): 19. 
Havent estat nomenats, d'acord amb el previst en el Decret d'aquesta Presidència del 12 de maig del 1956, publicat en el Diari Oficial de la Generalitat de Catalunya del juny del mateix any, delegats general i especial de la Generalitat de Catalunya a la República de l'Uruguai, amb residència a Montevideo, la senyora Margarida Xirgu i el senyor Miquel S. Cunillera respectivament, així com designats els senyors Josep Barberà i Benet, Francesc Bergós i Ribalta, Joan Garcia i Grau, i Llorenç Masferrer, perquè, segons proposta del delegat general senyora Margarida Xirgu, integrin la Delegació per al millor compliment de les tasques que a aquesta li pertoca realitzar;

Atès que, en previsió de qualsevulga contingència, és aconsellable procedir a la constitució de la Delegació de la Generalitat de Catalunya a la República de l'Uruguai, a fi que les persones que la integren puguin complir amb més eficiència la labor inherent a l'encàrrec que els ha estat fet;

\section{HE RESOLT:}

1r.- El delegat general senyora Margarida Xirgu desempenyarà les funcions de president de la Delegació de la Generalitat de Catalunya a la República de l'Uruguai, amb la comesa establerta en els apartats a), b) i c) de l'article 2n del Decret d'aquesta Presidència del 12 de maig del 1956;

2n.- En el cas d'absència o d'impossibilitat del delegat general senyora Margarida Xirgu, aquesta serà substituïda, amb totes les facultats i les obligacions que li són pròpies, pel delegat especial senyor Miquel S. Cunillera.

3r.- La senyora Margarida Xirgu, delegat general de la Generalitat de Catalunya a la República de l'Uruguai, fixarà la missió que, per al seu millor comès, correspondrà als senyors Josep Barberà i Benet, Francesc Bergós i Ribalta, Joan Garcia Grau i Llorenç Masferrer, que completen la Delegació.

Mèxic, 12 d'agost del 1959

Josep Tarradellas 
3

D'acord amb el previst en l'article $1 \mathrm{r}$ del Decret d'aquesta Presidència del 12 de maig del 1956, publicat en el Diari Oficial de la Generalitat de Catalunya del juny del mateix any, amb referència al nomenament de delegats generals i especials a Catalunya i en els territoris on l'emigració catalana ho justifiqui;

Atès que la República de l'Uruguai, tant pel nombre de catalans que hi resideixen com per les circumstàncies especials que en ells concorren, justifica plenament complir el previst en el Decret esmentat,

HE RESOLT:

Nomenar la senyora Margarida Xirgu delegat general de la Generalitat de Catalunya a la República de l'Uruguai, amb residència a la ciutat de Montevideo, amb les facultats i obligacions que aqueixa representació comporta.

Mèxic, 12 d'agost del 1959

Josep Tarradellas 
D'acord amb el previst en l'article $1 \mathrm{r}$ del Decret d'aquesta Presidència del 12 de maig del 1956, publicat en el Diari Oficial de la Generalitat de Catalunya del juny del mateix any, amb referència al nomenament de delegats generals i especials a Catalunya i en els territoris on l'emigració catalana ho justifiqui;

Atès que la República de l'Uruguai, tant pel nombre de catalans que hi resideixen com per les circumstàncies especials que en ells concorren, justifica plenament complir el previst en el Decret esmentat,

\section{HE RESOLT:}

Nomenar el senyor Miquel S. Cunillera delegat especial de la Generalitat de Catalunya a la República de l'Uruguai, amb residència a la ciutat de Montevideo, amb les facultats i obligacions que aqueixa representació comporta.

Mèxic, 12 d'agost del 1959

Josep Tarradellas 
5

Vista la comunicació del delegat general de la Generalitat de Catalunya a la República de l'Uruguai, senyora Margarida Xirgu, en què, per al millor compliment del previst en l'apartat a) de l'article $2 n$ del Decret d'aquesta Presidència de data 12 de maig del 1956, publicat en el Diari Oficial de la Generalitat de Catalunya del juny del mateix any, proposa el nomenament dels senyors Josep Barberà i Benet, Francesc Bergós i Ribalta, Joan Garcia Grau i Llorenç Masferrer, per tal que li prestin la seva collaboració en la labor que li és pròpia per la missió que li ha estat encomanada;

Atès que promoure i coordinar les tasques que portin a terme les organitzacions catalanes o constituïdes per catalans i nacionals de la República de l'Uruguai significa un esforç que justifica la proposta del delegat general a aqueixa República senyora Margarida Xirgu.

HE RESOLT:

Designar els senyors Josep Barberà i Benet, Francesc Bergós i Ribalta, Joan Garcia i Grau, i Llorenç Masferrer perquè integrin la Delegació de la Generalitat de Catalunya a la República de l’Uruguai.

Mèxic, 12 d'agost del 1959

Josep Tarradellas

[Segell de la Presidència de la Generalitat de Catalunya] 


\section{6}

[DELEgació General

DE LA

Generalitat de Catalunya]

\section{ACTA DE CONSTITUCIÓ}

Reunits a la ciutat de Montevideo (Uruguai), el dia 25 de març de 1960, al domicili de la senyora Margarida Xirgu, els senyors doctor Miquel Cunillera, Josep Barberà, Llorenç Masferrer i Joan Garcia Grau, es dóna lectura a les comunicacions de la Presidència de la Generalitat.

Tot seguit es deixa constància que el doctor Francesc Bergós, per raons personals, no accepta la designació, quedant, doncs, la Delegació General de la Generalitat de Catalunya constituïda de la següent manera: senyora Margarida Xirgu, president; doctor Miquel Cunillera, delegat especial i senyors Josep Barberà, Llorenç Masferrer i Joan Garcia Grau, aixecant-se a continuació l'acta corresponent i s'acorda enviar l'original de la mateixa a la Presidència de la Generalitat perquè n'hagi esment.

Margarida Xirgu, Joan Garcia Grau, Josep Barberà, Miquel Cunillera, Llorenç Masferrer 
Montevideo, 12 de octubre de 1961

Señor director del diario Acción

Honorable Senador Don Luis Batlle Berres

Ciudad

De nuestra más distinguida consideración.

Con gran sentimiento y profundo pesar, nos llega la fatal noticia del fallecimiento del ilustre hombre público y consejero nacional el ingeniero señor Manuel Rodríguez Correa.

Sabemos lo que ello significa, para el querido pueblo Oriental y para sus amigos políticos, la irreparable pérdida que hoy lamentan.

Es por ello que en esta hora de dolor, que compartimos, no queremos estar ausentes, y en nombre de nuestra sojuzgada y doliente democracia catalana, y de su legítimo representante el presidente de la Generalitat Honorable Señor José Tarradellas, hacemos llegar a usted, que tan íntimamente estuvo ligado a la vida del eminente repúblico y paladín de las libertades, los más fraternos sentimientos de pésame y dolor por la pérdida irreparable que para todos nos significa la desaparición física del leal y buen amigo el ingeniero señor Manuel Rodríguez Correa, rogando al señor senador quiera hacerlos extensivos a los dolientes familiares y amigos políticos y de Acción, que junto a él forjaron esta ejemplar y luminosa democracia uruguaya.

Reiterando los más cordiales sentimientos de amistad, quedamos de usted, attmte. affmos.

Margarita Xirgu

Delegada general

Doctor M. Cunillera R.

Delegado especial 


\section{8}

\section{[DELEgaCió GENERAL}

DE LA

Generalitat de Catalunya]

Buenos Aires, 7 de diciembre de 1961

Excelentísimo señor John Kennedy

Presidente de los Estados Unidos de Norte América

Washington

Señor presidente:

Ha producido sensación, no solo en el mundo artístico, sino también en el político, el festival musical realizado en la Casa Blanca, donde el eminente músico catalán Pablo Casals se consagró, una vez más, como el más grande artista contemporáneo.

Las palabras pronunciadas por el maestro al terminar el concierto; la presencia del gobernador de Puerto Rico, señor Luis Muñoz Marín, y la alta calidad de los asistentes coinciden con la significación histórica que atribuimos a vuestras palabras de encomio para el artista - que es símbolo de hombre libre y ejemplo de prístina pureza de convicciones y de rectitud de conducta - exilado de su patria, que pugna hace un cuarto de siglo por restaurar las libertades humanas, base, fundamento y razón de ser de las Naciones Unidas.

Deseamos felicitar al presidente de los Estados Unidos de Norte América por iniciativa tan plausible como simbólica. Esperamos que la significación de este gesto represente un verdadero cambio en la actitud política del Gobierno norteamericano, frente al problema de la Península Ibérica.

Por ello, como delegados de organismos políticamente representativos de las instituciones democráticas, que el pueblo de Cataluña se dió libremente en la última oportunidad en que pudo manifestarse, nos atrevemos a dirigiros este mensaje. Deseamos interpretar el acto de homenaje al maestro Pablo Casals como un preludio de la reparación total que la causa justísima de la democracia ibérica reclama. Y no como una com- 
pensación moral de una consumada injusticia histórica. No creemos de ello capaz al elevado espíritu de integridad y de juventud que encarnan vuestra personalidad, tan singularmente acrecentada por las esperanzas que ha inspirado en los corazones de los hombres libres del mundo.

Es desconcertante, para los hombres de sentimientos democráticos, el hecho de que existiendo identificación de conceptos jurídicos en los estadistas norteamericanos, en cuanto a los alcances de la libertad, la realidad intergiversable es que, a pesar de la tradicional postura asumida de adalides de la libertad política y económica, para extender a todo el género humano sus beneficios, bien poco han hecho desde el fin de la última guerra para captarse las simpatías de los hombres y pueblos sojuzgados por las tiranías.

Parecería que, hasta el momento presente, Estados Unidos no ha hecho otra cosa que silbar en la oscuridad. Y silbar en la oscuridad no trae la luz. Por el contrario, se enajenan poderosas fuentes de fuerzas potenciales que deberían ser sus naturales aliados, las cuales, decepcionadas y desesperanzadas, hoy vuelven la espalda a las grandes naciones democráticas, porque éstas han dado su apoyo a los tiranos, enemigos de la libertad y del sistema democrático de gobierno.

El franquismo, sucesor directo del nazismo hitleriano, constituye, cada día que pasa, un más grave peligro. Por esta razón, el problema de España exige una urgente solución de iniciativa internacional. El pueblo aspira hoy, en su gran mayoría, a derrocar la tiranía de Franco, para poderse equiparar a los demás países de occidente y ocupar su lugar en el mundo libre, en un plano de auténtica igualdad.

El gobierno de los Estados Unidos se halla abocado al siguiente dilema: o continuar entorpeciendo la legítima aspiración de los pueblos hispanos, arrojándolos hacia la orilla comunista, o bien coordinar sus esfuerzos con la oposición, para impulsar el recobramiento de la democracia. Todo parece estar muy maduro para realizar un eficiente cambio pacífico.

Cada día de demora en la realización de esta empresa, supone una agravación del peligro de violencia y hace que las masas democráticas peninsulares y sus dirigentes, desconcertados e indignados por la ceguera de la diplomacia occidental, se inclinen cada vez más por aceptar la ayuda de oriente. Es aleccionador, en este sentido, el reciente pacto que han suscrito el gobierno rebelde de Argentina y la Unión Soviética. 
Dos sofismas deben ser soslayados: la calumnia irónica, reiteradamente difundida, que atribuye a los pueblos de la Península ibérica la incapacidad para gobernarse. Aun contra el peso de la historia, se nos niega el derecho, que hoy ni se discute ya, a los pueblos «sin historia».

El segundo sofisma es el de afirmar que nada se puede hacer porque sería inmiscuirse en los asuntos internos de un país y ello atentaría contra su soberanía. Aparte que todo el mundo sabe que en España los atributos de la soberanía son detentados por la fuerza y no por la voluntad del pueblo, también conoce todo el mundo que una hipócrita neutralidad ha encubierto el apoyo diplomático, económico y militar a las fuerzas destructoras de las instituciones democráticas, que los españoles - particularmente los catalanes - aman y practican, desde hace siglos.

La información objetiva de la situación política internacional de la Península demuestra una influencia cada día más amplia de las fuerzas extremistas, debido al vacío producido por el apoliticismo obligado de grandes sectores; a las dificultades de propagación de los ideales democráticos y la imposibilidad de supervivencia de estas organizaciones, sometidas a implacable persecución y destrucción, y sin ayuda ninguna de las potencias que se asignan el liderazgo del mundo libre.

Estamos en un periodo prerevolucionario, en el cual las fuerzas decididamente dispuestas a la liberación y muchas fuerzas latentes que no actúan todavía, no hallan otra alternativa que la ofrecida por las organizaciones clandestinas extremistas. Este fenómeno es el resultado del apoyo diplomático y militar que los Estados Unidos han dado al franquismo y solamente una rectificación decidida y rápida podría eliminarlo. Esperemos que esta rectificación no se haga esperar y sea pronto una realidad.

Por lo que a Cataluña respecta, el Presidente de la Generalidad en el exilio, señor José Tarradellas, con la colaboración de numerosas personas, comisiones y delegaciones en el interior y el exterior del país, se halla preparado, con toda responsabilidad, para asumir la tarea de reconstrucción democrática. El respeto por la institución de la Generalidad es unánime y polariza a todos los catalanes, lo cual facilitaría grandemente el encauzamiento de los problemas de la inminente transformación política.

Para terminar, nos basta insistir, con E. John Hughes, que los valores democráticos identificados con la República española no podrán ser sal- 
vados con lemas, proclamas o discursos. Hace falta una sutil diplomacia al servicio de una voluntad de acción efectiva.

Saludamos a V. E. con la más alta consideración y respeto.

Dr. Juan Cuatrecasas, delegado general de la Generalidad en la República Argentina

Margarita Xirgu, delegada en Uruguay

Dr. José Santaló, delegado especial del presidente de la Generalidad

Dr. Miguel Cunillera, delegado en Uruguay 
9

Montevideo, 20 de enero de 1962

Señor ingeniero

Don Emilio A. Masobrio

Director de Paseos Municipales

Ciudad

Señor director:

Por las presentes líneas, me es muy grato hacerle presente el reconocimiento de nuestra colectividad, Delegación y en forma especial del Honorable Señor José Tarradellas, presidente de la Generalitat de Catalunya, por el acierto con que los servicios a su cargo han realizado en el embellecimiento de la plaza de esta ciudad y que lleva el nombre de nuestro Ilustre Presidente-Mártir don Luis Companys i Jover, víctima que fué del terror nazi-franquista.

Asimismo, agradecemos a usted y al Consejo Departamental, su gentileza en la reposición de la placa con que los compatriotas de Argentina colocaron en el monolito que lleva el nombre de dicha plaza y que desapareciera en su día.

Aprovecho esta magnífica oportunidad para saludar al señor director y reiterarle el afecto de nuestra más distinguida consideración personal,

Dr. Miguel S. Cunillera Rius

Delegado especial 